\title{
Natur- og kulturmiljø i Arktis
}

Grønland, Island og Svalbard

Rolf Haugaard Nielsen 


\section{Natur- og kulturmiljø i Arktis}

TemaNord 2006:536

(C) Nordisk Ministerråd, København 2006

ISBN 92-893-1337-4

Oversettelse: Marie Lier (www.biomlier.no)

Layout og produksjon: Naturplan (www.naturplan.dk)

Prepress: Digital XPress as

Trykk: UniTryk

Omslagsfoto: Karsten Scanack/Scanpix

Opplag: 500

Trykt på miljøvennlig papir som oppfyller kravene i den nordiske

miljøsvanemerkeordningen.

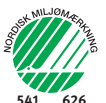

Publikasjonen kan bestilles på www.norden.org/order. Flere

publikasjoner på

www.norden.org/publikationer

Printed in Denmark

\begin{tabular}{|c|c|}
\hline Nordisk M & Nordisk Råd \\
\hline Stor & indstræde 18 \\
\hline en & enhag \\
\hline Telefon $(+45) 33960200$ & Telefon $(+45) 33960400$ \\
\hline $\operatorname{Fax}(+45) 33960202$ & $\operatorname{Fax}(+45) 33111870$ \\
\hline
\end{tabular}

www.norden.org

\section{Det nordiske samarbeidet}

Det nordiske samarbeidet er et av de eldste og mest omfattende regionale samarbeider i verden. Det omfatter Danmark, Finland, Island, Norge og Sverige samt Færøyene, Grønland og Åland. Samarbeidet styrker samhørigheten mellom de nordiske landene med respekt for de nasjonale forskjeller og likheter. Det øker mulighetene for å hevde Nordens interesser i omverdenen og fremme det gode naboskap.

Samarbeidet ble formalisert i 1952 med Nordisk Råds opprettelse som forum for parlamentarikerne og regjeringene i de nordiske land. I 1962 underskrev de nordiske landene Helsingforsavtalen, som siden har vært den grunnleggende rammen for det nordiske samarbeidet. I 1971 ble Nordisk Ministerråd opprettet som det formelle forum for å ivareta samarbeidet mellom de nordiske regjeringene og den politiske ledelsen i de selvstyrende områder, Færøyene, Grønland og Åland. 
Hva bør vernes i Arktis?

Behov for vern av truede kulturmiljø

Ferdselsslitasje skaper behov for miljøovervåkning

Forskning uten spor

Anbefaling: Arktisk utdannelse i naturformidling

Miljøundervisning skaper miljøbevissthet

Lokal Agenda 21 i Arktis

Pionerarbeid: Arktisk database over sjøfuglkolonier

Bunntrålig og skraping av muslinger i Arktis:

Sårbare habitater trenger beskyttelse

40 


\section{Utfordringer i Arktis}

Arktis har unike miljøverdier, men det er store og uløste utfordringer knyttet til bevaring og sikring av disse verdiene. Verdens uberørte naturområder blir stadig mindre, og noen av Jordas siste store områder med nesten uberørt natur finnes i Arktis. I denne storslåtte naturen er det mange verdifulle kulturminner som forteller om menneskenes bruk av naturen gjennom tidene. Natur - og kulturmiljøene i Arktis har stor verdi i seg selv og har samtidig stor betydning for bevaring av det biologiske mangfoldet. Den økende interessen for Arktis som reisemål og som referanseområde for miljøovervåkning har ført til økt fokus på Arktis.

En av de største og mest presserende miljøutfordringene i dag er å sørge for at lokale aktiviteter, som ressursutnyttelse, turisme og forskning, foregår innenfor miljømessige forsvarlige rammer. Man må sikre at det biologiske mangfoldet tas vare på og at uberørte naturområder og kulturminner ikke utsettes for betydelige inngrep og negative påvirkninger. Utslipp av drivhusgasser og miljøgifter fra kilder utenfor polarområdet er også en trussel mot miljøet og livsgrunnlaget for menneskene i de arktiske områdene.

\section{Handlingsplanen}

Den nordiske handlingsplanen for beskyttelse av natur- og kulturmiljøer i Arktis, Grønland, Island og Svalbard (Nord 1999:25) skal bidra til å få målsetningene i Den Nordiske Miljøstrategien ut i livet. Planen ble godkjent av de nordiske miljøministrene på Island 23. august 1999.

Planen er geografisk avgrensa til å omhandle Grønland, Island og Svalbard, samt de mellomliggende havområdene. Denne geografiske avgrensingen henger sammen med ønsket om å stimulere til et tettere samarbeid mellom de arktiske øygruppene i Norden.

Formålet med handlingsplanen er å sammenfatte behovene og foreslå prioriterte tiltak innenfor områdene biologisk mangfold, landskapsvern, kulturmiljø, friluftsliv, innsamling av miljødata og miljøovervåkning.

Ettersom kulturminner ikke inngår i det øvrige multilaterale arbeidet for å beskytte miljøet i Arktis, må handlingsplanens intensjon om å tenke helhetlig for ivareta beskyttelsen av natur- og kulturmiljøer, sies å være et pionerarbeid.

Handlingsplanen har valgt ut fire satsningsområder for et framtidig nordisk samarbeid om miljøvern 
i Arktis. Til hvert satsningsområde er det foreslått samarbeidsprosjekter, konkrete tiltak og generelle anbefalinger for det videre arbeidet med miljøvern i det arktiske Norden. Satsningsområdene er som følger:

1. Arktis som forbilde for det internasjonale arbeidet med å skape en bærekraftig utvikling.

2. Bedre kunnskapsgrunnlaget og styrke miljøovervåkningen i Arktis.

3. Bedre det nordiske samarbeidet om forvaltning og lovgivning i Arktis.

4. Holdningsskapende arbeid for å forebygge miljøkriminalitet $\mathrm{i}$ Arktis.

\section{Oppfølging av handlingsplanen}

Nordisk Ministerråd nedsatte sin egen Arktiske Styringsgruppe for å følge opp forslagene i handlingsplanen. Styringsgruppa har hatt et nært samarbeid med Arbeidsgruppa for Natur, Friluftsliv og Kulturmiljø, samt med den Nordiske Miljødatagruppa. Arbeidet er nå avsluttet etter at det er blitt gjennomført ni prosjekter, som dekker et vidt spekter innenfor vern av kultur- og naturmiljø på Grønland, Island og Svalbard. Denne brosjyra gir et overblikk over prosjektenes innhold og resultater.
Handlingsplanen omfatter ikke klima og miljøgifter i Arktis, fordi dette skulle følges opp i egne nordiske miljøstrategier. 16. mars 2006 vedtok miljøministrene en strategi for klima og miljøgifter i Arktis.

\section{Veien videre}

Mange utfordringer, som er knyttet til miljøvern i Arktis, må løses gjennom et samarbeid mellom de arktiske landene. Det finnes en stor grad av felles interesser og utfordringer innenfor miljø og forvaltningen av naturressursene. Prosjektene, som er gjennomført av Nordisk Ministerråd og som presenteres i denne brosjyra, er et nordisk bidrag og supplement til samarbeidet om miljøvern i Arktisk Råd og Barentssamarbeidet. Vi håper at denne helhetstilnærmingen til natur- og kulturmiljøet i Arktis vil bli videreført også i andre internasjonale fora i Arktis.

Prosjektene har bidratt til å styrke det nordiske samarbeidet for miljøvern og bærekraftig bruk av naturressursene. Prosjektene har også videreutviklet et felles kunnskapsgrunnlag. Nordisk Ministerråd håper at nettverkene, som er blitt etablert mellom forvaltningsmyndighetene på Grønland, Island og Svalbard, vil utvikle seg videre etter av prosjektet er avsluttet.
Prosjektene gir en rekke anbefalinger - herunder forslag til konkrete initiativ, som bør følges opp. Om forslagene iverksettes, vil det være en suksess for det arktiske samarbeidet.

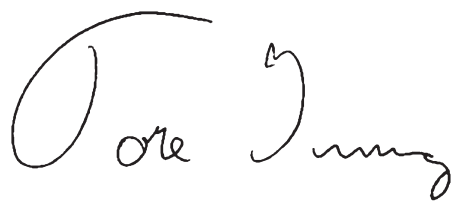

Tore Ising

Formann for den Arktiske Styringsgruppa 


\section{Hva bør vernes i Arktis?}

$\varnothing$ kende ferdsel sliter $p a ̊$ den sårbare naturen og kulturmiljøene på Grønland, Island og Svalbard. Derfor er det behov for objektive vernekriterier som tar utgangspunkt $i$ samspillet mellom menneskets historie, samfunnenes utvikling og den arktiske naturen.

Turismen og friluftslivet i Arktis er i vekst. Det skaper $ø$ kt ferdsel som medfører risiko for at det unike landskapet og kulturmiljøene på Grønland, Island og Svalbard $ø$ delegges. Det økende presset på den sårbare arktiske naturen og fortidens kulturminner krever at miljøforvaltningen har objektive vernekriterier som bygger på helhetsvurderinger av samspillet mellom nåtidens aktiviteter, naturen og kulturmiljøene. En viktig utfordring er å kunne avgjøre hvilke verdier som er knyttet til kulturminnene og landskapet og hvor betydningsfulle verdiene er, slik at det kan prioriteres mellom dem.

Det er store forekjeller mellom de klimatiske, naturgeografiske og

De bratte klippeveggene på Festningsodden, Svalbard, brukes som referanseprofil og ekskursjonssted for studenter (Foto: Winfried Dallmann).

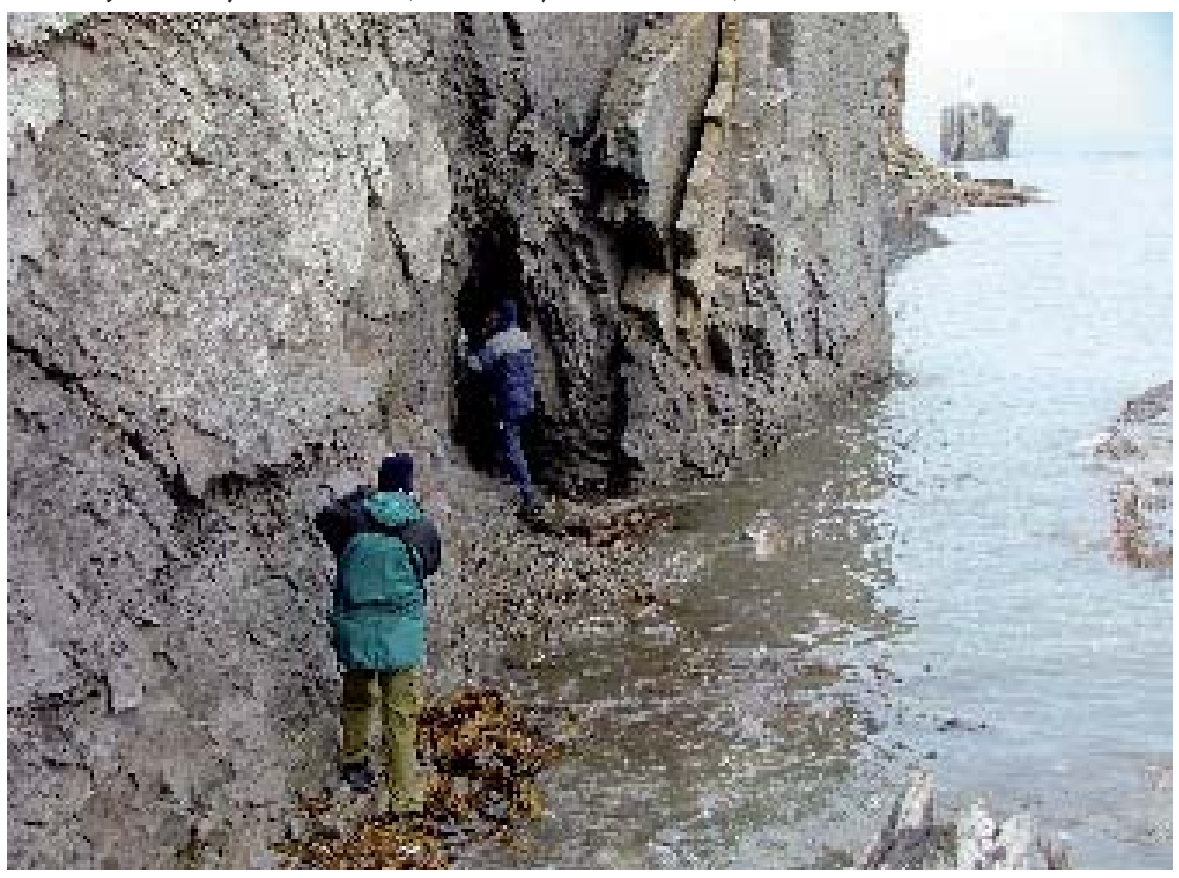




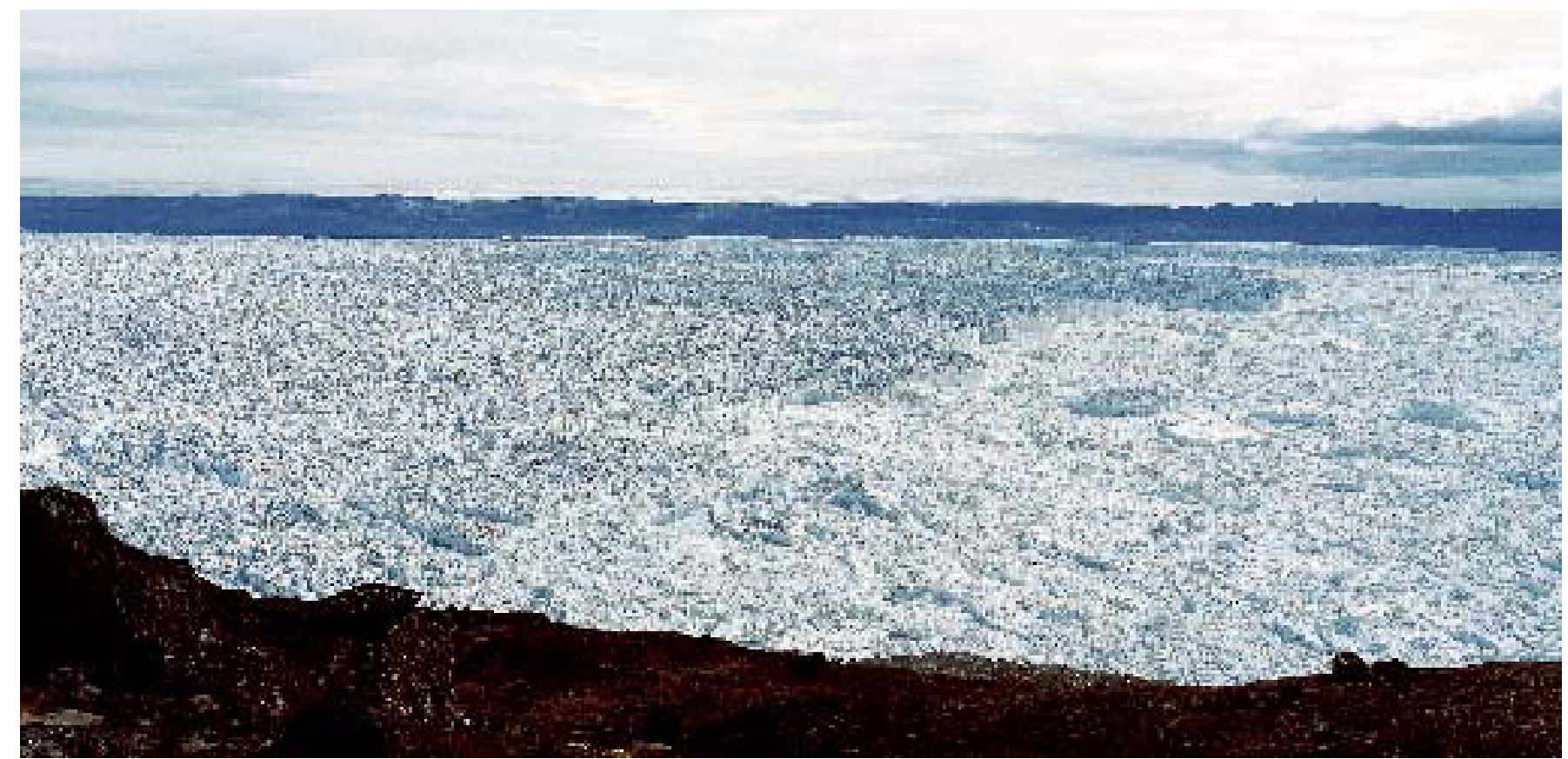

En tidel av all isen, som årlig kalver fra innlandsisen, kommer fra Illulissat Fjord (foto: Jakob Lautrup, GEUS).

samfunnsmessige forholdene på Grønland, Island og Svalbard, og det har hittil preget forvaltningsmyndighetenes prioriteringer. På Grønland har livet og økonomien alltid vært knyttet til dyr og planter, derfor har forvaltningsmyndighetene fokusert på de levende ressursene, samt kulturminnene. På Island, hvor menneskene har måtte kjempe mot vulkanutbrudd og jordskjelv, har geologi og landskap en helt annen betydning både i den folkelige bevisstheten og i forvaltningen. Svalbards rolle, som forskjellige nasjoners "gruvekoloni", har medført at geologiske forekomster tradisjonelt sett er blitt ansett som en sentral del av det økonomiske grunnlaget, men ikke som noe verneverdig i seg selv.

\section{Helhetssyn på landskap og kulturminner}

Ei prosjektgruppe under Nordisk Ministerråd har nå arbeidet med et sett generelle vernekriterier for kulturminner og landskap som kan brukes av forvaltningsmyndighetene på Grønland, Island og Svalbard. Målet er å prioritere naturområder og kulturminner som til sammen illustrerer et tverrsnitt av historien og helheten. Hver for seg kan de utvalgte områdene enten representere noe sjeldent, eller et fenomen som tidligere har vært typisk.

Kulturminner er uerstattelige kilder til viten om historien, om tidligere tiders bruk av naturens ressurser, og om menneskenes $\emptyset$ konomiske, sosiale og religiøse liv. Tilsvarende er nåtidens landskap kilder til forståelse av Jordas opprinnelse og utvikling. Mange geologiske formasjoner i Arktis rommer opplysninger om fortidas geologiske prosesser. Disse er viktige for å kunne forstå framtidige klimaendringer og naturkatastrofer.

\section{Livet ved Ilulissat Isfjord}

For å belyse forvaltningsmessige problemstilinger i forhold til vern og beskyttelse av natur- og kulturmiljø, har prosjektgruppa beskrevet en rekke lokaliteter på Grønland, Island og Svalbard.

I 2004 ble Ilulissat Isfjord på Vestgrønland tatt opp på UNESCOs liste over verdensarvområder med den begrunnelse at "Isfjorden er et unikt naturfenomen og et område med ekstrem skjønnhet”. Nettopp Isfjorden er et godt eksempel på hvorfor samspillet mellom naturen, de biologiske ressursene og menneskenes kulturhistorie bør ses på som en helhet.

Innerst i fjorden er Ilulissat Isbre, hvorfra det kalver 35 kubikkilometer is hvert år, noe som utgjør en tildel av den totale ismengden som kalver fra den grønlandske innlandsisen. De gigantiske isfjellene rekker ofte 100 meter over vannoverflata. Isens bevegelser i 


\section{Utvelgelse av landskap og kulturminner}

De nye vernekriteriene bygger på et helhetssyn, og på et overordnet nivå er de nesten like for kulturmiljø og landskap, mens det av praktiske og faglige grunner er forskjeller på et mer detaljert nivå.

Kriterier for utvelgelse:

- Sikring av naturarven med vekt på geologisk mangfold og et rent miljø.

- Sikring av kulturarven med fokus på kulturhistorisk mangfold og representativitet på lokalt, nasjonalt og internasjonalt nivå.

- Grunnlag for kunnskap: Kulturminnene og de geologiske formasjoners betydning for forskning, undervisning og formidling.

- Grunnlag for opplevelser og rekreasjon: Estetisk verdi, uberørthet, sjeldenhet og symbolverdi.

Kriterier for prioriteringer:

- Sårbarhet: Tåler landskapet eller kulturminnene inngrep og forandring som for eksempel i form av økt ferdsel?

- Trusler: Er det tale om en akutt trussel som gjør det nødvendig med øyeblikkelige tiltak? Eller er det behov for å forebygge framtidige skader, eksempelvis som følge av en forventet økt mengde turister?

- Tilgjengelighet: Forbedret tilgjengelighet kan øke risikoen for ødeleggende slitasje, men kan også forbedre bruksverdien av et område. Derfor må fordeler og ulemper veies opp mot hverandre.

- Bruksverdi: Kulturminner er ikke bare spor etter fortidens mennesker, men omfatter også økonomiske verdier i dag, som for eksempel hus og produksjonsanlegg. Naturområdene har bruksverdi for næringslivet, ikke minst i forbindelse med turisme. Kommersiell bruk av kulturminner og natur stiller derfor store krav til bærekraftig forvaltning.

- Bevaringstilstand: Det må vurderes om et kulturminnes tilstand er god nok til at det er mulig å bevare det som kilde til kunnskap og opplevelse. fjorden medfører en høy biologisk produksjon. I lange perioder har naturen på denne måten skapt gode betingelser for fangst og fiske, og menneskenes historie på stedet startet allerede for 4000 år siden med Saqqaq-kulturens innvandring nordfra.

I de senere årene er Ilulissat blitt et sentrum for turismen på Grønland, og det stigende antallet besøkende kan utgjøre en trussel mot områdets sårbare natur og kulturminner. Derfor samarbeider miljømyndighetene og næringslivet nå om å utvikle handlingsplaner som skal sikre at Isfjordens unike natur og enestående kulturminner brukes på en bærekraftig måte i framtida.

\section{Islands historiske tingsted}

Tingvellir er det mest berømte stedet på Island. Mange viktige beslutninger i landets historie er blitt tatt her, hvor Alltinget møttes gjennom århundrer for å utstede

Rester etter en tingbod på Tingvellir (foto: Kristinn Magnússon).

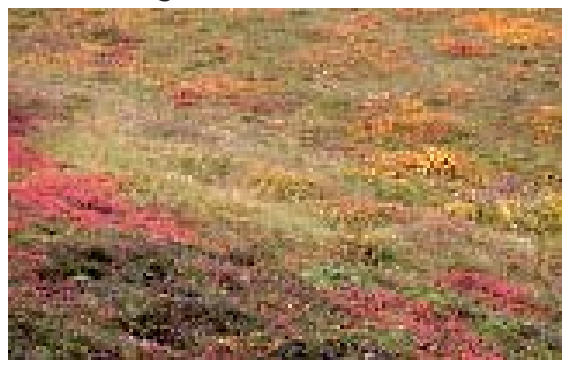




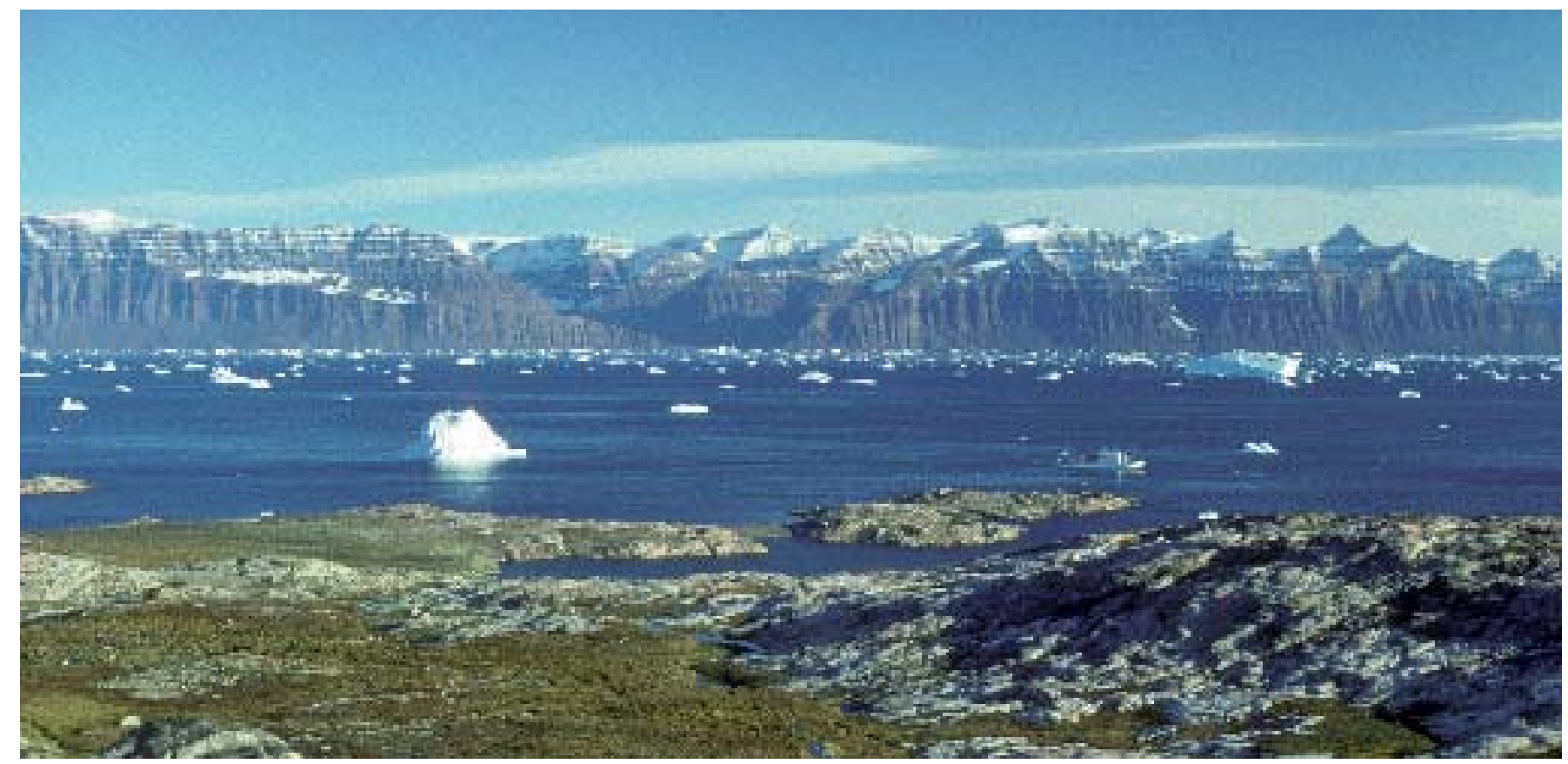

Hav, is og land møtes på Grønland i store dimensjoner (foto: John Frikke).

lover og avsi dommer. Tingvellir ble utnevnt til nasjonalpark allerede i 1928, og i 2004 ble det gamle tingstedet tatt opp på UNESCOs verdensarvliste.

Det finnes minst 50 ruiner på Tingvellir som i dag først og fremst er en turistattraksjon. Fram til 1998 var det blitt tråkket opp et stort antall stier overalt i området, og stiene gikk ofte rett over mindre synlige ruiner. Men så ble det startet opp et stort arbeid for å motvirke ytterligere slitasje og ødeleggelse av kulturminnene og området som helhet. Antall stier er redusert, og en stor platting av tre er bygget ved Lögberg, der historikerne mener at lovstifting og domsavsigelse fant sted. Her kan turistene nå samles rundt en guide uten at det skader kulturminnene.

\section{Svalbards geologiske tidstavle} På sørsiden av Isfjorden på Svalbards største øy, Spitsbergen, lig- ger Festningsodden. De loddrette klippeveggene inneholder en unik geologisk profil, fordi lagrekken er nesten ubrutt fra Permtidens begynnelse for 290 millioner år siden og fram til Tertiærtidens start for 65 millioner år siden. Festningen brukes som referanseprofil i geologisk forskning og som ekskursjonssted for studenter. På odden er det dessuten funnet velbevarte fotavtrykk etter dinosauren Iguanodon som levde i Krittiden. Festningen er utsatt for naturlig erosjon fra bølger og havis.

Lokaliteten er lett tilgjengelig med båt, noe som øker den vitenskapelige verdien som referanseprofil, men samtidig øker risikoen for slitasje. Festningen er fredet, slik at det verken er tillatt å bygge, bore eller sprenge der. Ferdsel skal skje uten at det skader naturmiljøet, og myndighetene kan om nødvendig regulere eller forby ferdsel i spesielt sårbare områder.
Det poengteres at fossile spor etter dinosaurer ikke må fjernes eller skades.

Rapport: TemaNord 2005:541 "Vernekriterier for geologiske elementer og kulturminner i Arktis". http://www.norden.org/pub/sk/ showpub.asp?pubnr=2005:541. Søk også etter rapporten/emnet på: www.norden.org/pub 


\section{Behov for vern av truede kulturmiljø}

Kulturminner i Arktis forteller om befolkningenes tilpasning til et kaldt klima og deres imponerende evne til å overleve under vanskelige forhold. I dag er kulturminnene noen steder truet av økende ferdsel og andre steder av fraflytting.

Naturen i Arktis er tøff med kulturminnene. Overlatt til seg selv, utsettes de for klimatiske prosesser som frostsprengning og erosjon, et sårbart vegetasjonsdekke og nedbrytning forårsaket av dyr. Når folk flytter fra bygdene og inn til byene, blir sporene etter menne- skenes historie derfor ofte raskt mindre synlige.

Andre steder er fortidens kulturmiljø truet av økt menneskelig aktivitet på grunn av tilflytting og distriktsutvikling; bygging av industri, boliger og feriehytter, veianlegg og ridestier, pløying av ny mark, bruk av moderne landbruksmaskiner og planting av skog. I tillegg kommer slitasje fra ferdsel på grunn av turisme, friluftsliv og forskning.

Hovedutfordringene er de samme på Grønland, Island og Svalbard til tross for områdenes vidt forskjellige klima, geografi og historie.

Paleoeskimoisk ruin ved Amdrup Land på Nordøstgrønland (foto: Claus Andreasen).

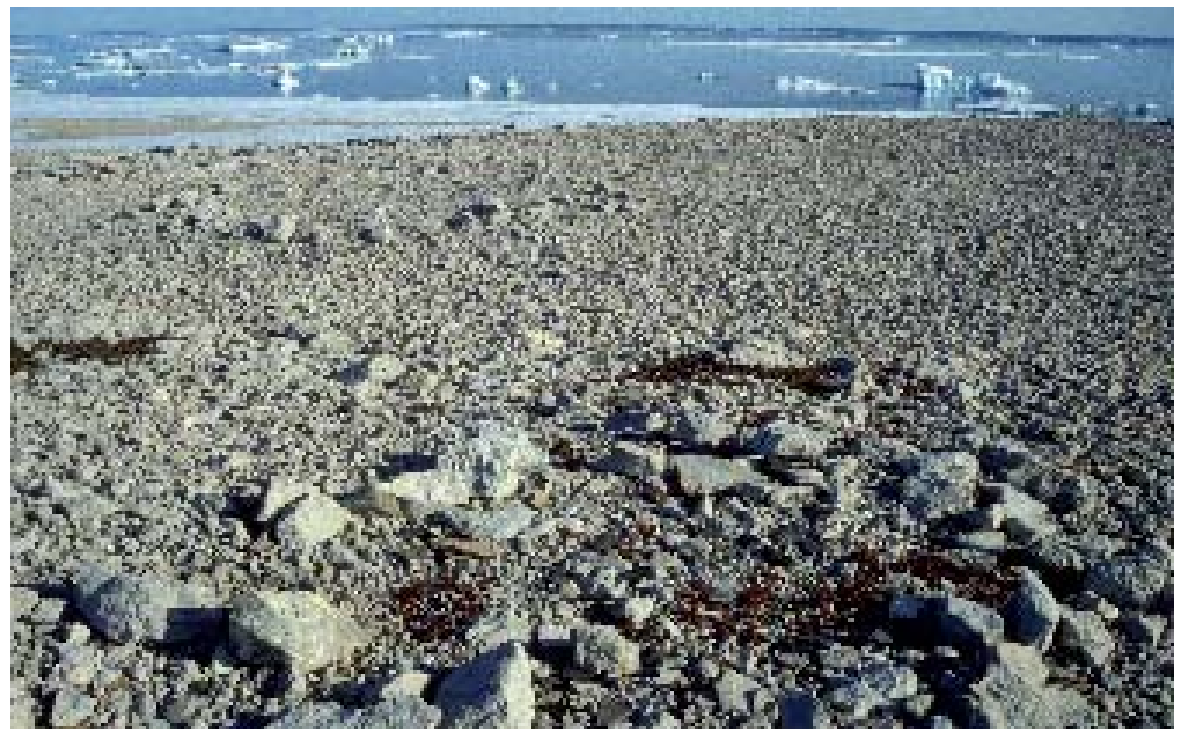




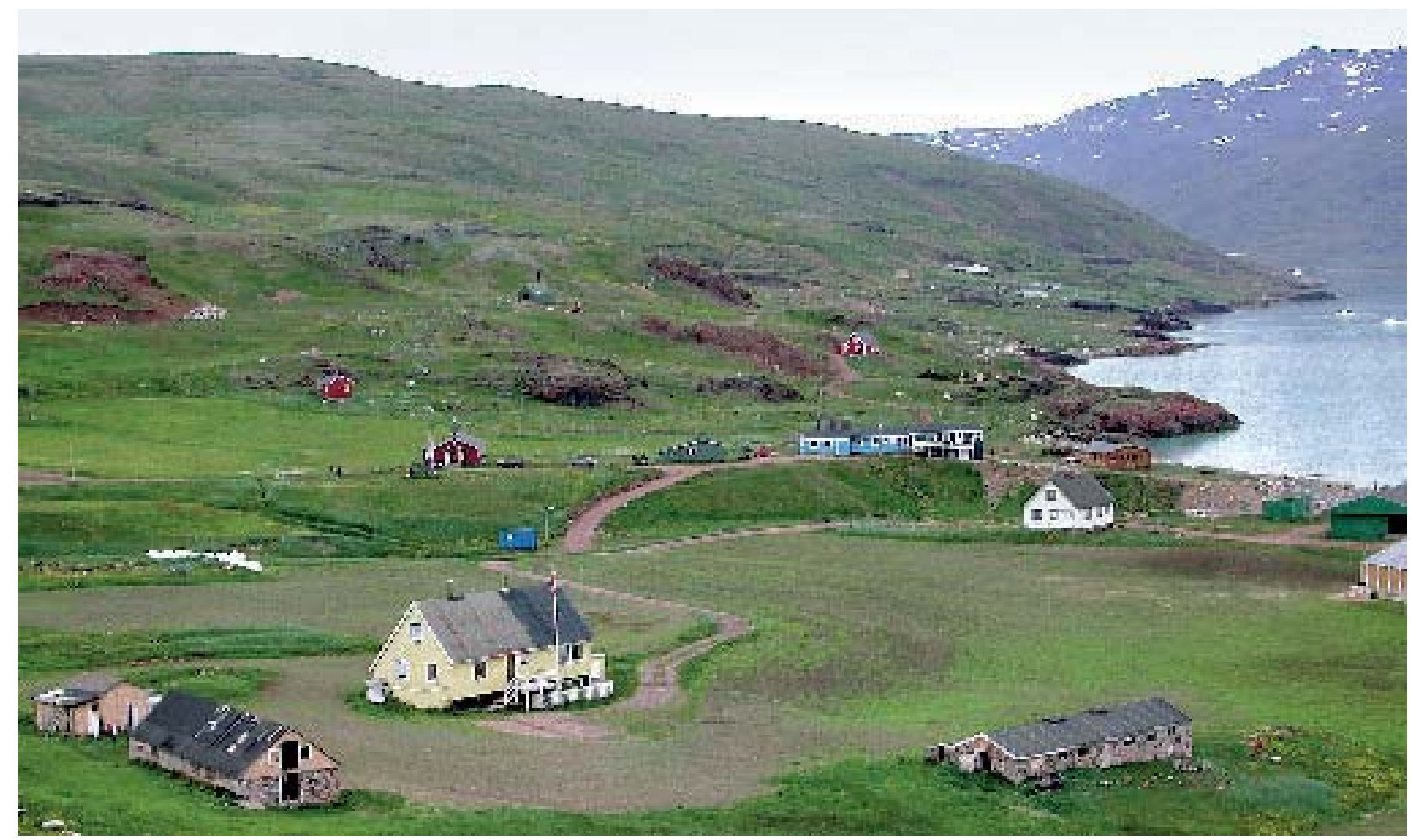

Bygda Qassiarssuk ligger på samme sted som Erik Raudes gård Brattahlid. Ruinene etter nordboernes gårdshus og kirken ses midt i bildet (foto: Susan Barr).

Hvis det skal lykkes å bevare et representativt utvalg av fortidens kulturmiljø, er det nødvendig med nye tiltak på nasjonalt, regionalt og lokalt plan. Ei ekspertgruppe under Nordisk Ministerråd har laget en anbefaling om hva som bør gjøres, og samtidig har gruppa utpekt en rekke verneverdige kulturmiljø i hvert av det tre områdene.

Sammenhengen mellom naturgrunnlaget og kulturmiljøet er utgangspunktet for utvelgelsen av kulturminnene. Avhengigheten av naturen er et grunnvilkår i Arktis. Samspillet mellom menneskene og miljøet er derfor grunnlaget som gjør det mulig å forstå hvordan menneskene gjennom tidene her levd og klart seg under disse spesielle forholdene langt mot nord.

\section{Historie på Grønland gjennom årtusener}

Nasjonalparken på Nordøstgrønland er verdens største verneområde og inneholder et enestående kulturmiljø som tydeliggjør sammenhengen mellom natur og kultur. Her finnes det spor etter de eldste paleoeskimoiske kulturene og fra forfedrene til de nåværende grønlandske inuittene, thuleeskimoene, som ved omkring år 1100 innvandret fra Canada og siden spredte seg ned langs kysten av Grønland. Fra senere perioder har nasjonalparken spor etter dansk og norsk fangstvirksomhet, samt fra amerikanernes opphold i området under andre verdenskrig.
All ferdsel i nasjonalparken krever en tillatelse fra Grønlands hjemmestyre, og det er i dag stort sett vitenskapelige ekspedisjoner som ferdes i denne gigantiske ødemarka. Imidlertid, har kulturlandskapet en opplevelsesverdi som med tiden sannsynligvis vil bli utnyttet kommersielt.

Et annet unikt kulturmiljø på Grønland er Brattahlid like ved Narsarsuaq, der de første nordboerne fra Island slo seg ned $\mathrm{i}$ år 985 under ledelse av Erik Raude. Det var også herfra vikingene senere reiste til Amerika. På grunn av den norrøne historien besøkes stedet hvert år av flere tusen turister. I 2000 satte Grønlands Nasjonalmuseum og Arkiv i gang et prosjekt for vedlikehold av ruinene og etablering av stier gjen- 


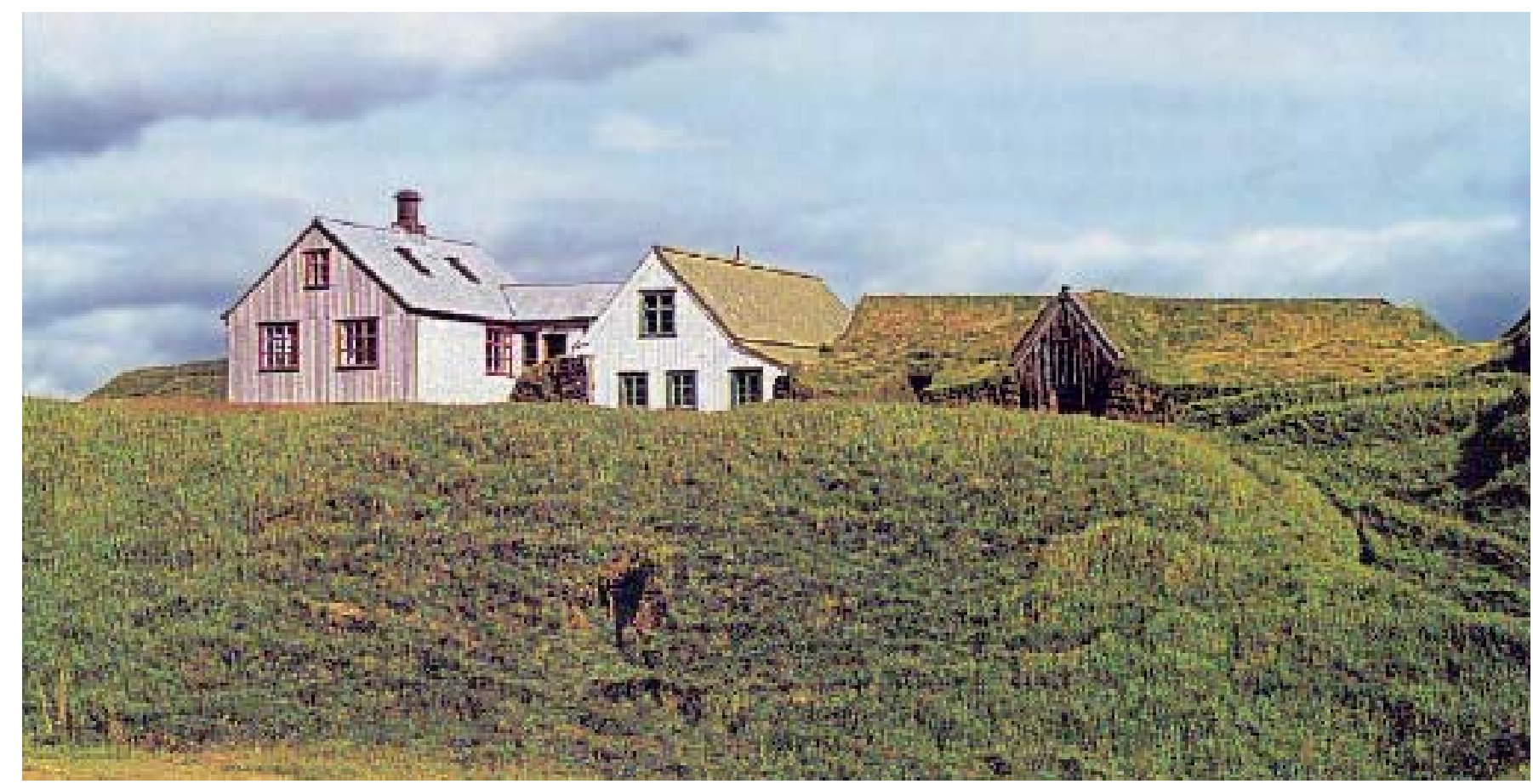

Tre generasjoner av hovedbygninger på gården Keldur. Fra venstre ses det nyeste huset fra 1937, i midten et hus fra 1800 -tallet og til høyre, langhuset fra middelalderen (foto: Thór Hjaltalín).

nom området. Dessuten er det bygd plattinger for å unngå ferdsel på ruinene.

\section{En middelaldergård på Island}

Gården Keldur, som ligger nær Rangárvallasyssel på Sydlandet på Island, er et enestående kulturmiljø. Det består av over 30 bygninger og ruiner, som er bygd mellom år 1000-1200 og 1937. Den eldste delen av gården er gulvet i et langhus av torv og stein, samt en 25 meter lang underjordisk tunnel som har fungert som rømningsvei i urolige perioder. Langhuset brant ned på 14001500 -tallet og ble siden bygget opp igjen. Gården er nevnt i flere islandske kilder fra middelalderen, bl.a. i Njåls saga. Nasjonalmuseet kjøpte Keldur i 1947, og omfattende reparasjoner ble utført i årene 1997-2000. Keldur er for tiden ikke åpen for allmennheten.

\section{Spor etter gruvedrift på Svalbard}

Ny-Ålesund på Svalbard var tidligere en gruveby, der det ble brutt kull. Gruvedriften startet i 1916 og stanset i 1962 etter ei ulykke der 21 mennesker mistet livet. I driftsperioden ble det etablert flere gruver, jernbaner, veier, broer, kaianlegg og brakker. Etter driftstansen ble gruveområdet forlatt, og det er nå en ruinpark med forvridde metalldeler, splintret treverk og rester etter bygninger og jernbaner. Siden 1999 er flere broer i gruveområdet blitt satt i stand, og miljøfarlig avfall er fjernet. I dag er selve bebyggelsen vedlikeholdt, og flere av bygningene brukes som forskningsstasjoner. Det er en utfordring å bevare kulturminneverdiene samtidig som bebyggelsen utvikles.
Rapport: TemaNord 2005:552 “Kulturmiljøer i Arktis - Prinsipper for bærekraftig forvaltning" www.norden.org/pub/sk/ showpub.asp?pubnr=2005:552. Søk også etter rapporten/emnet på: www.norden.org/pub 


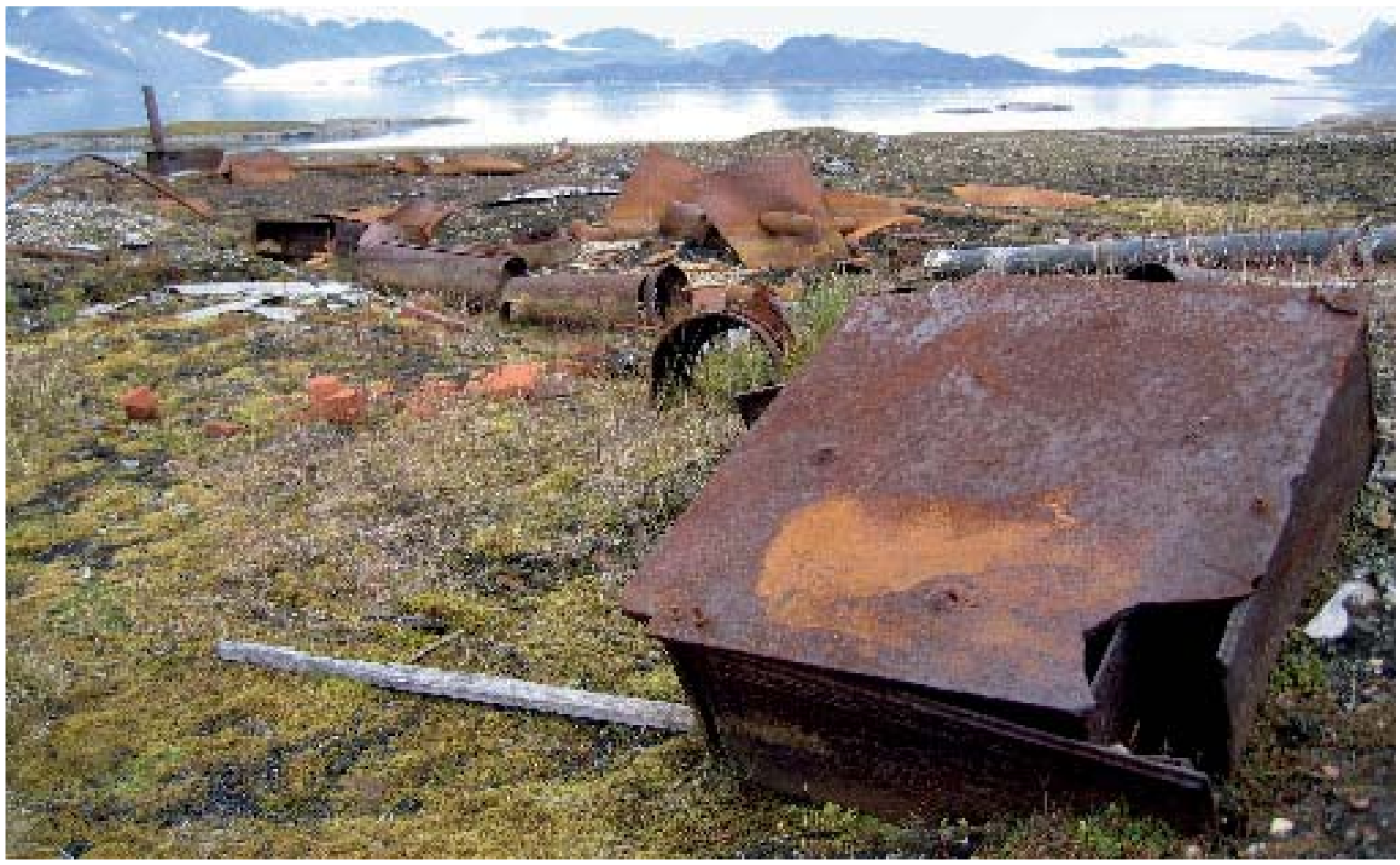

Rester etter driften av ei kullgruve på Svalbard (foto: Susan Barr).

\section{Anbefalinger for bærekraftig forvaltning}

Nasjonalt plan:

- Myndighetene bør vurdere behovet for lovendringer vedrørende bevaring av kulturminner, og begrepet kulturmiljø bør skrives inn i lovgivningen.

- Det bør innføres en undersøkelsesplikt i forbindelse med prosjekter som berører kulturmiljøene, slik at konsekvensene kan vurderes på forhånd.

- All organisert turistvirksomhet, som påvirker høyt prioriterte kulturminner, bør bruke kvalifiserte guider.

Regionalt plan:

- Areal- og forvaltningsplaner bør være i forkant av utviklingen og fastsette retningslinjer for hvordan kulturmiljøet skal bevares og utvikles i samspill med stedets egenart, særpreg og opprinnelige byggeskikk.

- Det bør utvikles retningslinjer for å unngå ferdselsslitasje på steder med mange eller et økende antall besøkende.

Lokalt plan:

- Lokale myndigheter bør legge opp til styrket deltagelse og engasjement fra lokalbefolkningen i befolkede områder.

- Det bør etter behov innføres soner med ferdselsforbud.

- Det bør innføres meldeplikt for alle besøkende til spesielt bevaringsverdige områder. Det kan gi et overblikk over antallet, og samtidig kan man gi de besøkende nødvendig informasjon om bærekraftig adferd. 


\section{Ferdselsslitasje skaper behov for miljøovervåkning}

\begin{abstract}
Mange sårbare arktiske naturområder og kulturmiljø, som før var utilgjengelige, kan nå nås med moderne transportmidler. Ferdselen øker og dermed slitasjen. Derfor er miljøovervåkning nødvendig.
\end{abstract}

Når et arktisk naturområde eller kulturminne besøkes av et stort antall mennesker, sliter ferdselen hardt på området. Vegetasjonsdekket er mange steder spinkelt og fragmentert, og plantene vokser på et tynt humuslag. Det gjør vegetasjonen sårbar ovenfor mekanisk slitasje. Samtidig medfører de lave temperaturene og den korte vekstsesongen at plantenes evne til å gjenetablere seg er dårlig. Ved lang tids slitasje kan vegetasjonsdekke forsvinne helt, og det vil ofte skape erosjon som kan utløse jordskred, spesielt der terrenget skråner.

\section{Ut i naturen}

Den vakre og uberørte arktiske naturen tiltrekker seg et $ø k t$ antall turister, og samtidig vokser omfanget av befolkningens friluftsliv. På Island er mange islendinger på ferie i høylandet, der de drar på fotturer og rideturer, mens hundesledetur og snøscooter er populært på Grønland. På Svalbard går det flere og flere cruiseskip langs

Sti på Sermiutsletta ved Illulsiat Isfjord på Grønland (foto: Joel Berglund).

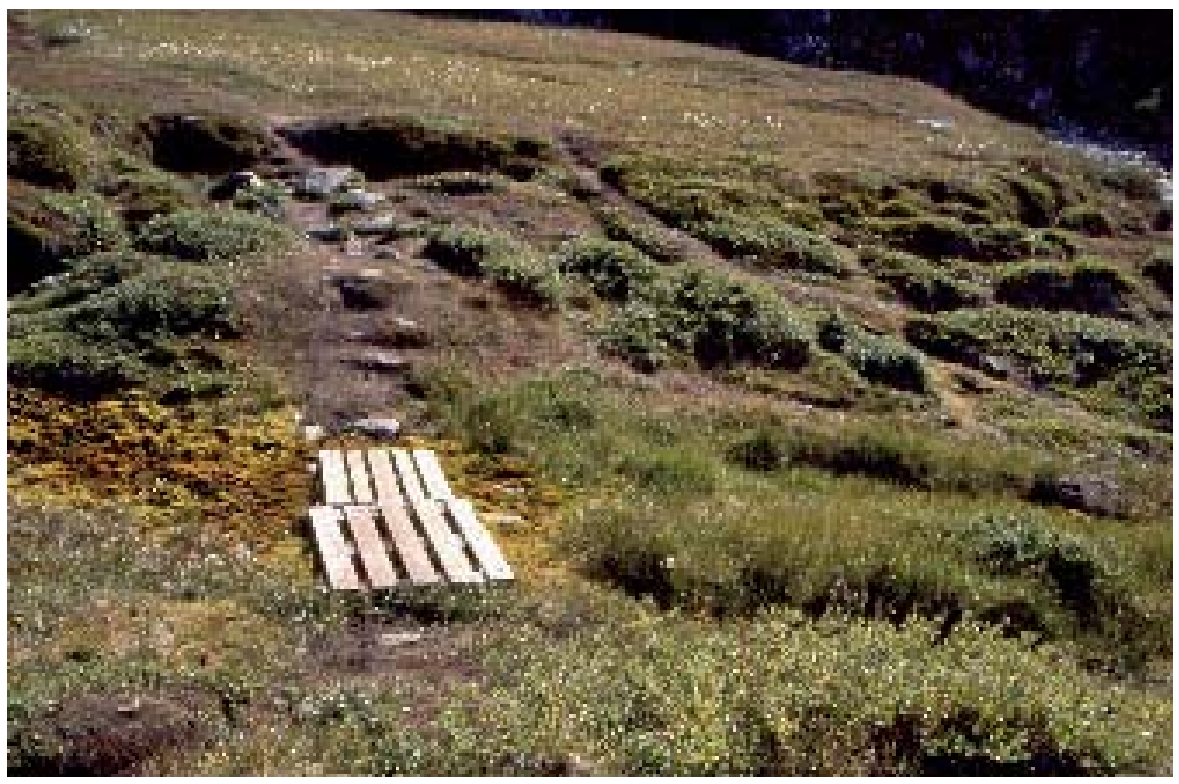




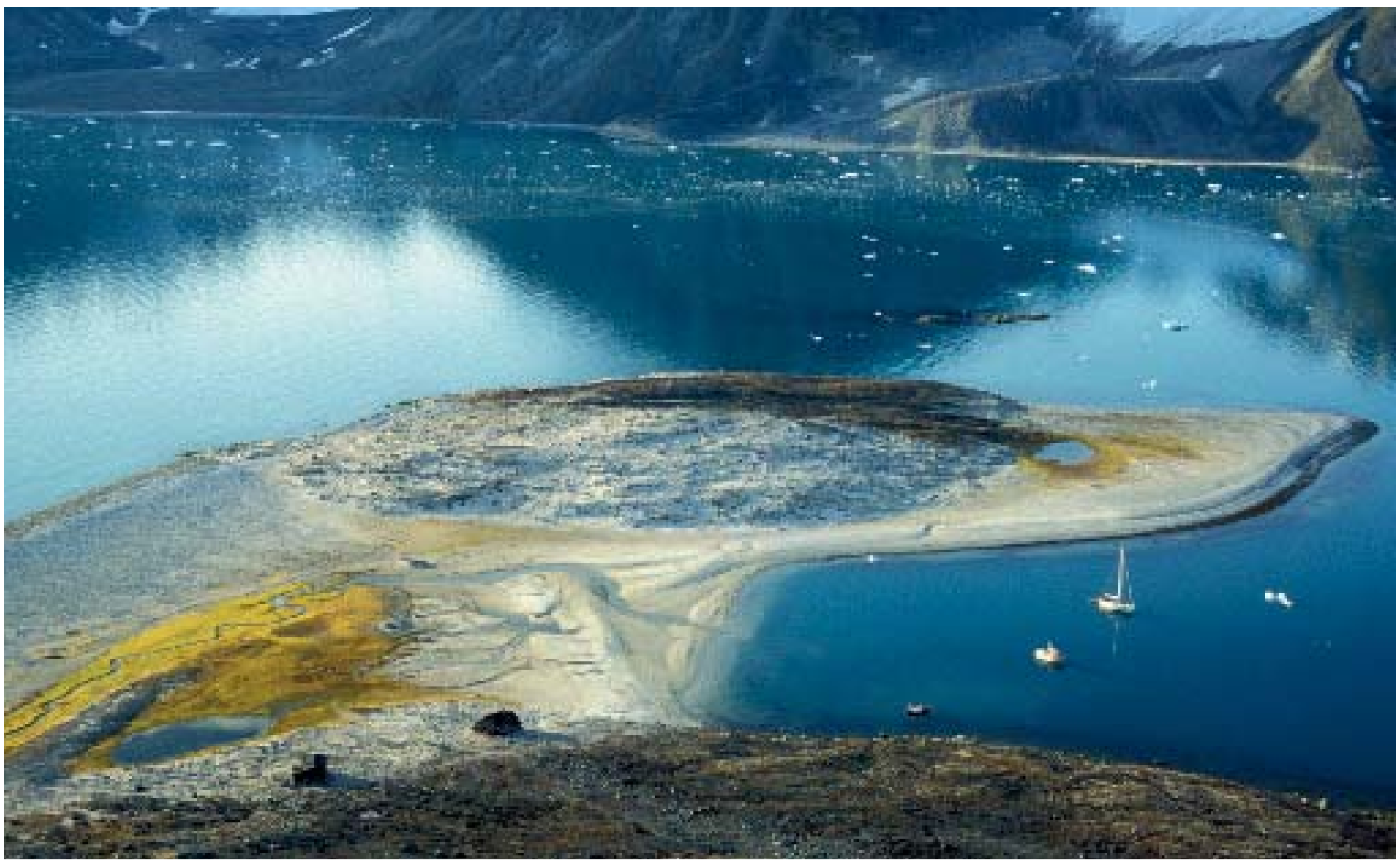

Vegetasjonen på Gravneset på Svalbard er slitt ned av turister (foto: Kirsti Høgvard).

kysten. Enkelte ganger går opp til flere tusen turister i land samtidig, noe som er en stor belastning, spesielt for den sårbare vegetasjonen.

De omfattende friluftsaktivitetene medfører at mange naturområder og kulturmiljø er langt mer utsatt for slitasje enn tidligere. Når det gjelder kulturminner, er det også et økende problem med suvenirjegere.

Presset på naturen og kulturmiljøene i Arktis gjør det nødvendig å overvåke miljøet, slik at myndighetene får mulighet til å gripe inn i tide og regulere ferdselen, for å unngå uopprettelige skader. Men hvordan kan miljøet overvåkes effektivt til en fornuftig pris?
For å finne svaret på dette spørsmålet har ei arbeidsgruppe under Nordisk Ministerråd testet forskjellige miljøovervåkningsmetoder på ti lokaliteter på Grønland, Island og Svalbard. I forbindelse med prosjektet ble det utarbeidet et nytt observasjonsskjema med beskrivende tilstandsklasser, og de første erfaringene med bruk av skjemaet er positive.

\section{Test i praksis}

Et av de undersøkte kulturmiljøene på Grønland er boplassen Sermermiut ved Ilulissat Isfjord. Her finnes det mer enn 20 ruiner, som tidsmessig spenner fra Saqqaqkulturens ankomst for 4000 år siden og fram til 1850, da boplassene ble forlatt. Semermiut besøkes hvert år av 10000 turister, og ferdselen har ført til et nettverk av stier i området. Vegetasjonen er nesten nedslitt rundt den mest synlige ruinen. På Sermermiut ble overvåkning utført ved hjelp av tegning og fotografering, og ruinenes tilstand ble beskrevet $i$ observasjonsskjemaet. Muligheten for overvåkning av Sermermiut ved bruk av satellitter vurderes.

Skaftefell nasjonalpark på Island har øyas største isbre, Vatnajökul, og flere aktive vulkaner. Nasjonalparken er kandidat for å bli innskrevet på UNESCOs verdensarvliste. Hvis det skjer, vil det utvilsomt føre til flere besøkende, noe som vil øke slitasjen på stier og kulturminner. Det er derfor viktig å starte miljøovervåkningen nå, slik at man kan oppdage even- 
tuelle forandringer, sånn som økt erosjon. I Skaftafell ble det brukt flyfotografering, observasjonsskjemaer, oppmåling av kulturminnene og flyfotografering av lokaliteter som er truet av erosjon.

På Svalbard er miljøovervåkning, ved bruk av fotografering og flybilder, utført på Gravneset på Nordvest-Spitsbergen. På Gravneset finnes en av øygruppas største gravplasser fra hvalfangsttida mellom år 1600 og 1800 . Vegetasjonen er helt slitt vekk i store områder.

Gruppa anbefaler at miljøovervåkningen videreføres på alle de ti undersøkte lokalitetene.

\section{Overblikk og detaljer}

Erfaringene fra prosjektet viser at det er hensiktsmessig med miljøovervåkning på to nivå; et overordnet og et detaljert.

I mange sammenhenger er det viktig å følge utviklingen på et stort antall lokaliteter for å oppdage overordna tendenser. Her er flybilder og satellittbilder effektive, men kostbare metoder. Ofte kan man også oppnå gode resultater ved tilstandsvurdering og observasjonsskjema. Metoden er billig, hvis overvåkningen utføres i forbindelse med andre tilsynsoppgaver.
Detaljert overvåkning anbefales på mindre, avgrensa lokaliteter, der det er mange besøkende. Fotografering, og da spesielt bruk av tredimensjonale bilder, er en god metode.

En tilfredsstillende overvåkning av naturen og kulturmiljøene vil kreve større økonomiske ressurser enn det som brukes på Grønland, Island og Svalbard i dag. Gruppa anbefaler at myndighetene starter et langtidsprogram for miljøovervåkning, der man samtidig videreutvikler og forbedrer metodene.

Rapport: TemaNord 2003:530

"Miljøovervåkning av ferdselsslitasje - Grønland, Island og Svalbard". http://www.norden.org/pub/sk/ showpub.asp?pubnr=2003:530. Søk også etter rapporten/emnet på: www.norden.org/pub 

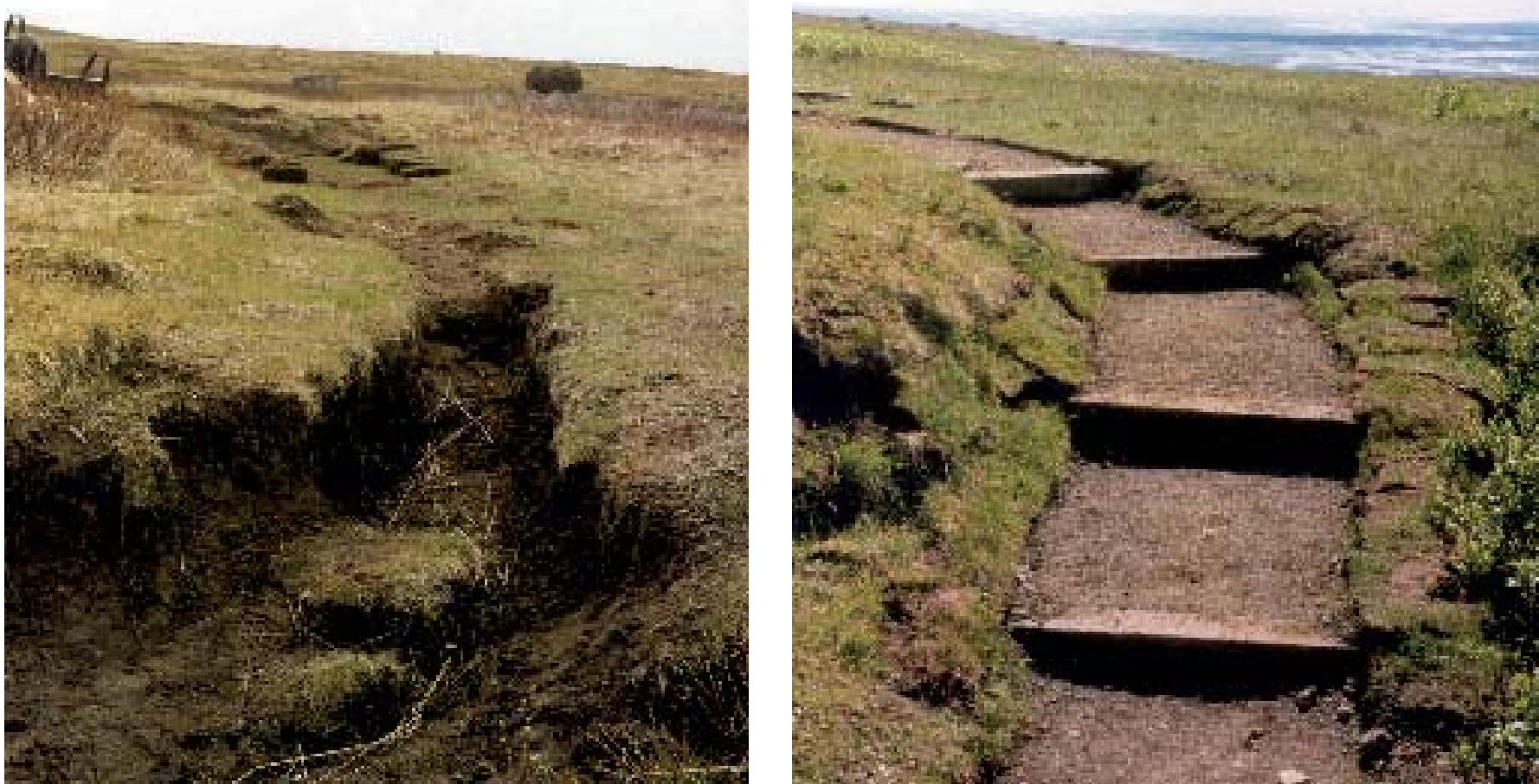

Ved Skaftafell kan erosjon, som følge av ferdsel, begrenses ved tilrettelegging (foto: Chas Goemans).

\section{Metoder for miljøovervåkning}

Hyppig anvendte metoder for miljøovervåkning er fotografering på stedet, flybilder og satellittbilder. Når et område fotograferes med jevne mellomrom, kan bildene sammenlignes for å avklare om miljøtilstanden har endret seg. I dag er det også mulig å lage tredimensjonale bilder.

Flybilder er en effektiv metode for å overvåke store områder, og spesielt infrarøde bilder er godt egnet til å avsløre endringer i vegetasjonen. I de senere årene er det blitt mulig å bruke ubemannede mikrohelikoptre, som kan utstyres med ulike sensorer, noe som gir mange nye muligheter.

Satellittbilder er velegnet til kartlegging og overvåkning av landskap og vegetasjon i stor skala. I de senere årene er nye satellitter i stand til å levere bilder i høy oppløsning, helt ned til 5 meter. Med slike bilder kan man for eksempel registrere kjørespor. 


\section{Forskning uten spor}

Arktis spiller en sentral rolle for den internasjonale forskningen på klima, miljø, geologi og naturressurser, og forskerne fär tilgang på uberørte naturområder. Forskning har en enorm signalverdi, og det er viktig at feltarbeidet utføres forsvarlig.

Forskere som arbeider på Grønland, Island og Svalbard utfører ofte feltarbeid i fjernt beliggende og øde områder. Områdene er lite tilgjengelige, med unike miljøverdier som er særlig sårbare og beskyttet av strenge miljøkrav. De store avstandene, det barske klimaet og fraværet av veier og annen infrastruktur medfører at forskerne ofte har behov for å bruke helikopter, terrenggående kjøretøy og store båter. Disse store og tunge kjøretøyene belaster miljøet i større grad, i form av utslipp og slitasje på terrenget, enn mindre tungt utstyr som kan benyttes $i$ lettere tilgjengelige områder.

Forskning har en sterk holdningsskapende effekt, både i forbindelse med utdannelse og ovenfor befolkningen som helhet. Derfor bør forskerne være ekstra oppmerksomme på deres miljøansvar. Samtidig er det viktig at ikke forskningen i seg selv påvirker miljøet det forskes i.
Ei prosjektgruppe under Nordisk Ministerråd har identifisert en rekke utfordringer som forskerne, deres institusjoner og myndighetene står ovenfor når miljøhensyn skal integreres i feltarbeidet. Ved å arbeide målrettet med utfordringene, vil det være mulig å redusere miljøbelastningene ved feltarbeid i forbindelse med forskning og utdanning.

\section{Helhetsplanlegging}

For å unngå unødvendige belastninger er det nødvendig med en overordnet planlegging og miljøvurdering før et forskningsprosjekt settes i gang. Samtidig kan koordinering av forskjellige prosjekter og ved gjenbruk og flerbruk av data redusere belastningen fra tung logistikk. I den forbindelse bør det etableres prosjektdatabaser for hele regionen. Samtidig kan arealet av det berørte området som brukes til feltarbeid, gjøres minst mulig ved å konsentrere infrastrukturen til bestemte områder.

\section{De formelle rammene}

Miljølovgivningen inneholder ofte et komplisert regelverk for områdene der forskerne arbeider. Derfor er det viktig å sikre at det finnes tilstrekkelig og brukervennlig informasjon til forskere og studenter, så de vet hvilke regler som skal overholdes. Dessuten 


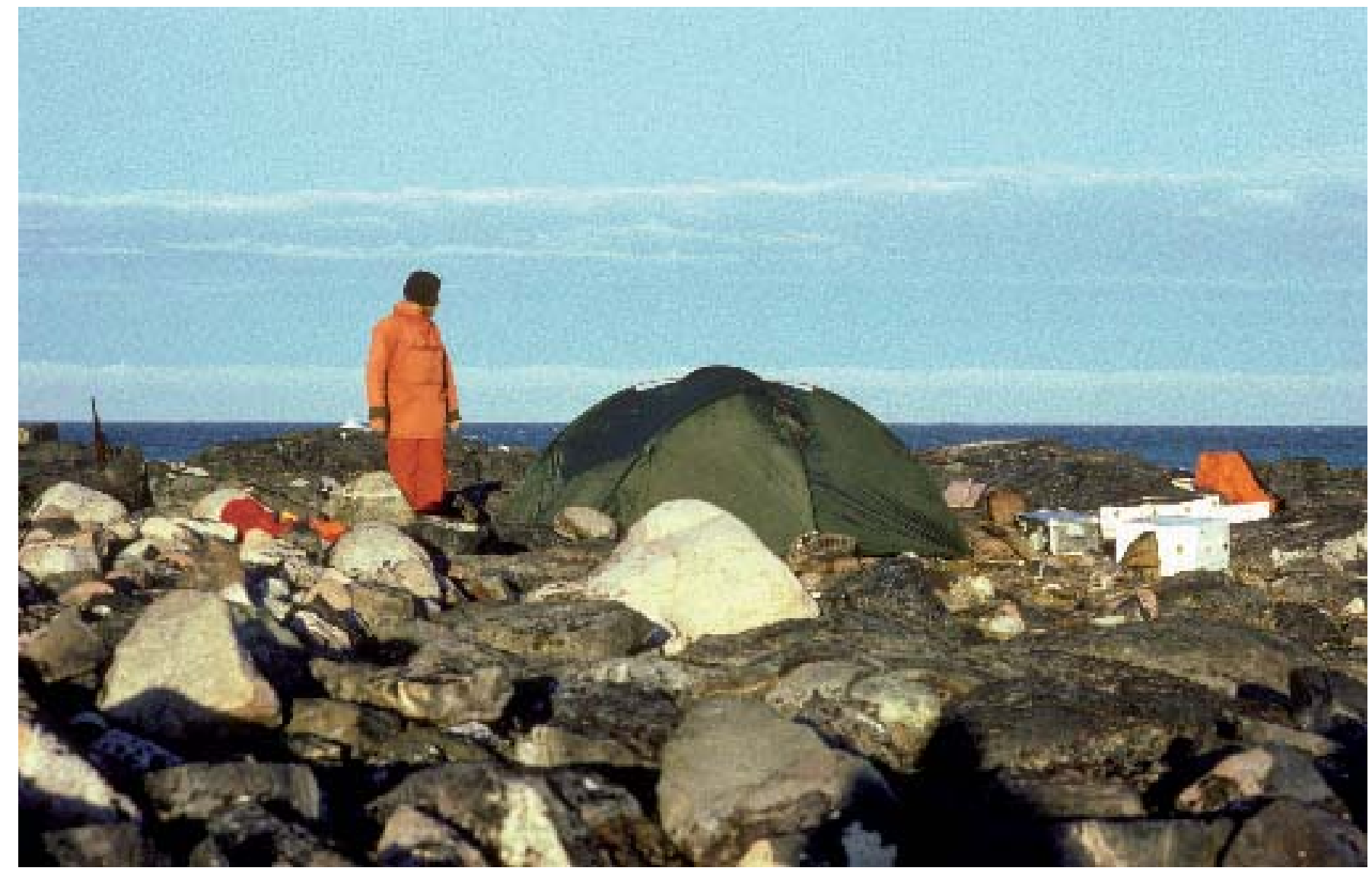

Feltleir etablert på steingrunn, for å unngå skader på vegetasjonen (foto: John Frikke).

Transport med lastbil setter spor. Nederst forsøker man å dekke igjen sporene (foto: Snorri Páll Snoraason).

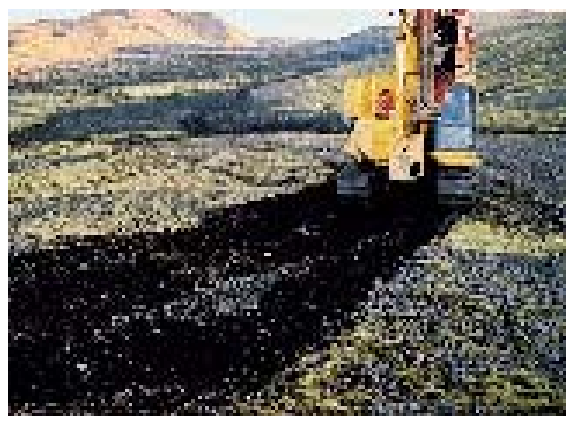

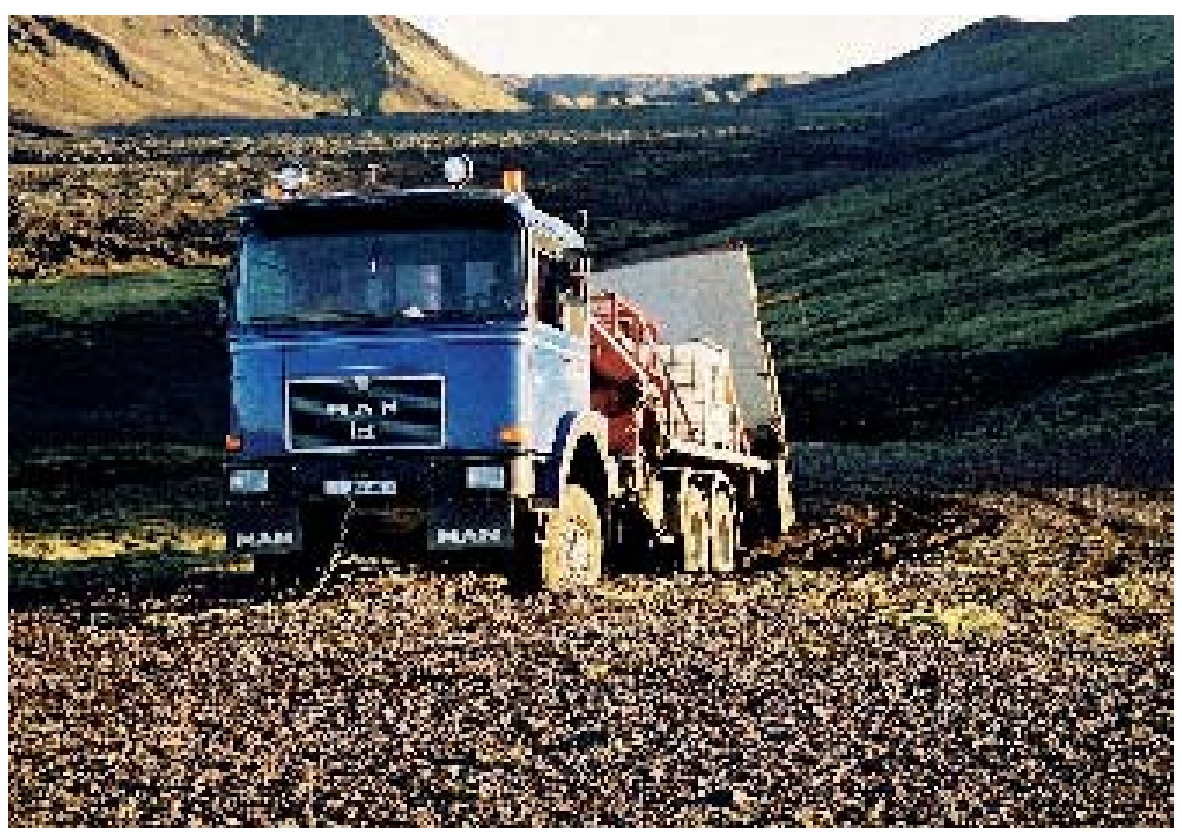


bør myndighetene utvikle bedre og mer rasjonelle administrative rutiner i forbindelse med at det gis tillatelser til forskning i uberørte naturområder.

\section{Kunnskap om miljøet}

Hvilke miljøhensyn som må tas ved feltarbeid avhenger av sårbarheten i det aktuelle området. Ofte har man ikke tilstrekkelig kunnskap, eller så vet ikke forskerne hvor de skal finne den. Derfor er det nødvendig å bygge opp databaser med tilstrekkelig og relevant informasjon om miljøforholdene og miljøbelastningen i de områdene som er forskningsmessige interessante.

\section{Arbeid i felt}

Ved feltarbeid kan gode rutiner minimalisere miljøbelastningen. Ved å bruke den beste tilgjengelige teknologien, er det ofte mulig å redusere slitasjen som følge av ferdsel. All transport bør skje på tidspunkt og i områder, der skadevirkningene har minst mulig betydning. I prosjekt som innebærer håndtering $\mathrm{av} \mathrm{dyr,} \mathrm{er}$ det viktig å vurdere om det finnes alternative metoder og lokaliteter, og i hvilken årstid en forstyrrelse har minst mulig innvirkning på dyrene. Avslutningsvis, en forsvarlig håndtering av avfall og utslipp er alltid en utfordring.

\section{Arktisk forskning har global betydning}

Den internasjonale interessen for arktisk forskning er økende, spesielt når det gjelder økologi, miljøforskning, klima og geologi.

$\emptyset$ kosystemene og de biologiske miljøene i Arktis er enkle og forholdsvis upåvirka av menneskelig aktivitet og de er derfor velegnet til basale økologiske studier. Fysiske prosesser som energiutveksling mellom hav, is og atmosfære har avgjørende betydning for det globale klimaet. På Svalbard og Grønland er alle Jordas geologiske tidsperioder representert, og de geologiske strukturene er lett tilgjengelige på grunn av et tynt jordlag og vegetasjonsdekke. Arktis spiller en sentral rolle i miljøforskningen for forståelsen av transport av miljøgifter og forurensning over store avstander.

Den tre kilometer tykke iskappa på Grønland, Innlandsisen, er et unikt fenomen på den nordlige halvkule. Der er det boret ut iskjerner som har gitt meget nøyaktige data om Jordas klima og atmosfærens kjemi de siste 130000 år.

Island er en ung vulkansk øy som spiller en sentral rolle for forståelsen av kontinentaldrift og vulkanisme. De geologiske forholdene gir enestående muligheter for utvikling av geotermisk energi. Dessuten er jorderosjonen kraftigere her enn nesten alle andre steder i verden, og den islandske forskningen på erosjonsprosesser er av de ledende internasjonalt.

Svalbard er biologisk sett et av de rikeste landområdene i Høyarktis, og iskantsonen er av de mest produktive havområdene i verden. Svalbard spiller en sentral rolle i forskningen på nordlys, og øyene er velegnet til nedlasting av data fra satellitter i polare baner. Avslutningsvis, de geologiske formasjonene på Svalbard avspeiler forholdene i de omkringliggende havområdene, noe som er interessant i forbindelse med oljeleting.

Rapport: TemaNord 2005:547

"Forskning uten spor". http:

//www.norden.org/pub/sk/

showpub.asp?pubnr=2005:547.

Søk også etter rapporten/emnet på:

www.norden.org/pub 


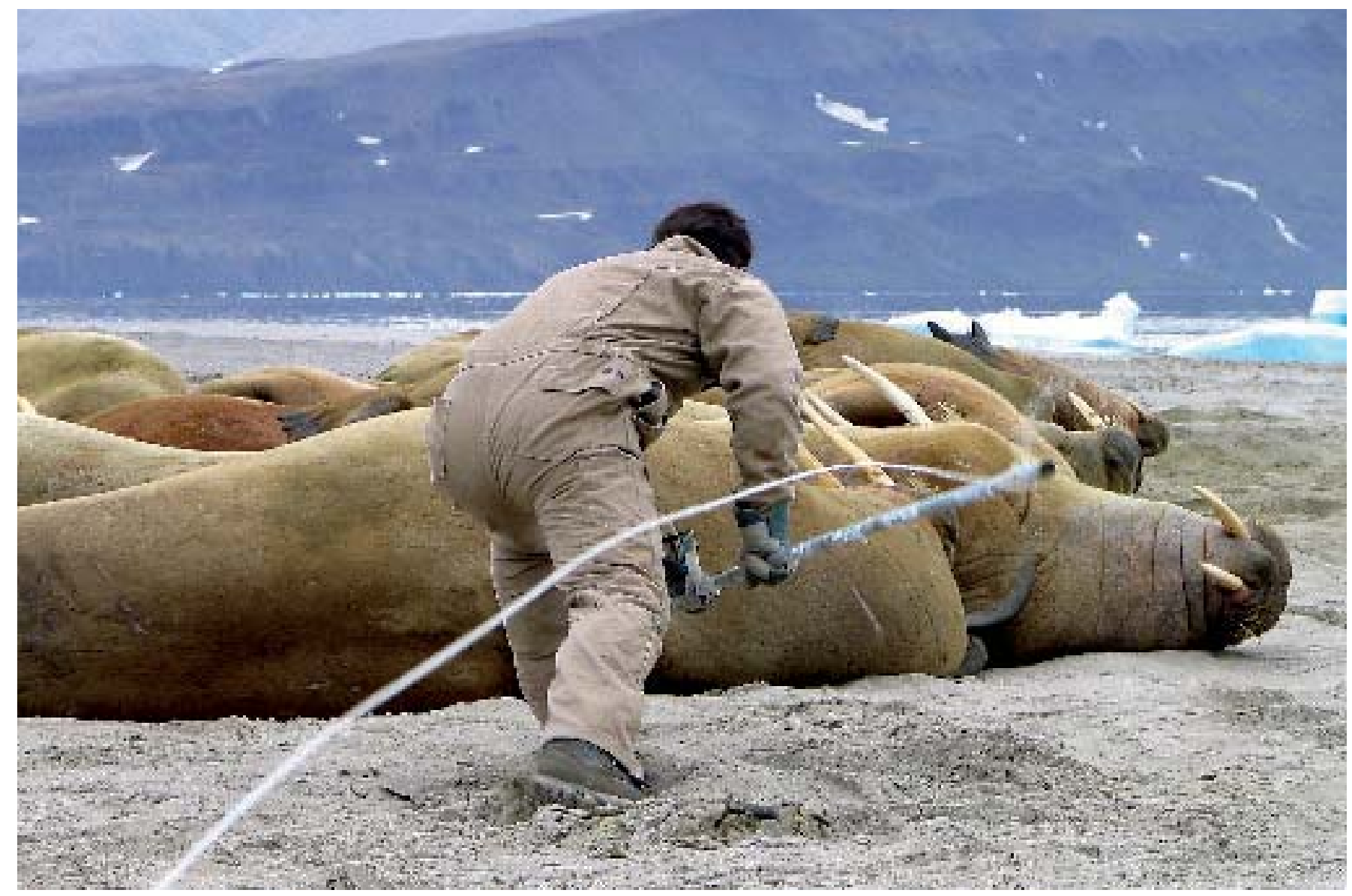

Satellitsender settes på hvalross med håndkraft (foto: Mario Acquarone).

Harpunspiss med satellitsender (foto: Jørgen Søholm).

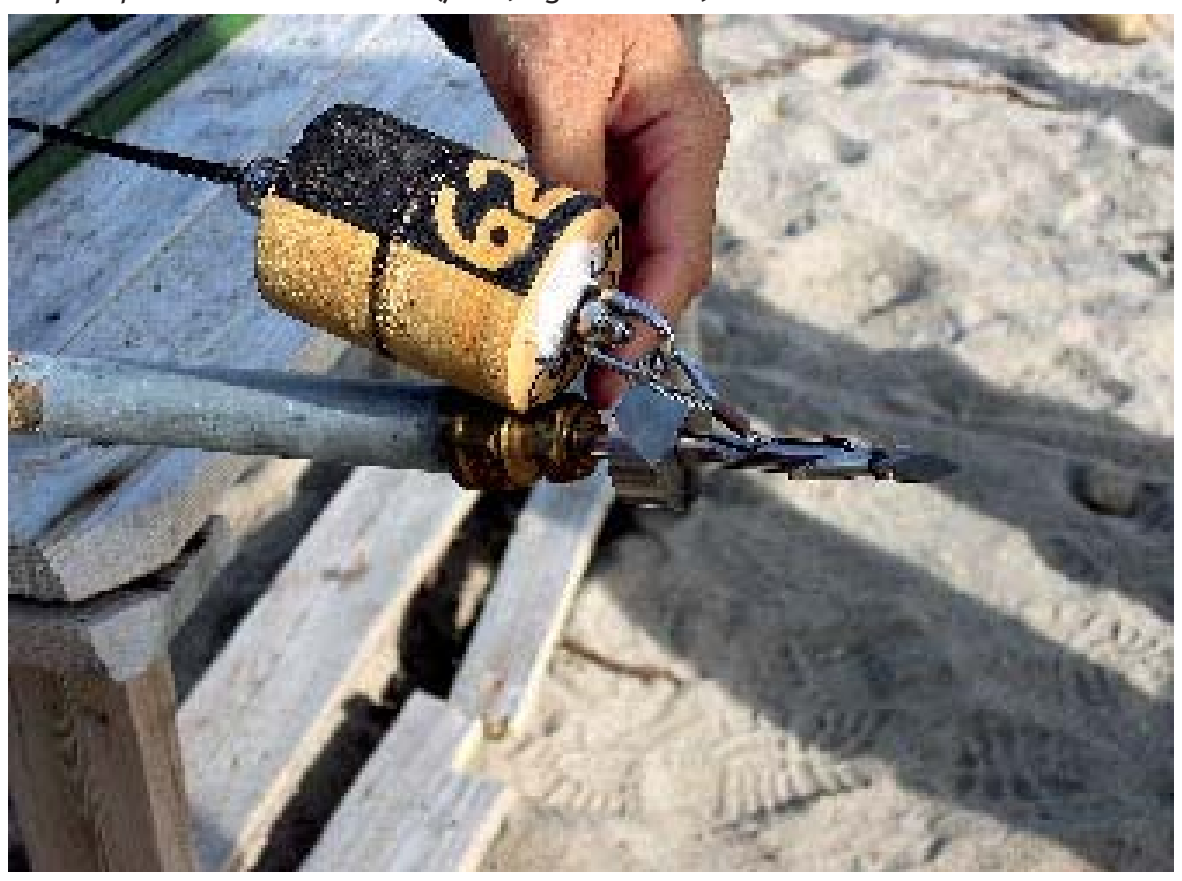




\section{Anbefaling: Arktisk utdannelse i naturformidling}

Naturveiledere kan skape økt miljøbevissthet i befolkningen og medvirke til at veksten i turismen ikke belaster naturen eller kulturminnene unødig. Av den grunn anbefales det at det opprettes en nordisk utdannelse for naturveiledere, guider og andre som arbeider med naturveiledning i Arktis.

Naturveiledere har mange funksjoner. De er bindeleddet mellom miljøet, forvaltningen, lokalbefolkningen og turistene, og de gjør at man kommer tettere på naturen ved å formidle kunnskap om naturhistorie, kultur, natur- vern og om bærekraftig utvikling. Mange steder utfører også naturveiledere tilsyn av naturområdene og kulturminnene og tar seg av vedlikehold.

Island har tretti års erfaring med naturveiledere. De spiller en viktig rolle for naturvernet i nasjonalparkene og andre verneområder. I tillegg benytter turistbransjen seg i økende grad av naturveilederen, i takt med at kundene blir mer og mer miljøbevisste. De islandske veilederne arbeider spesielt med formidling og tilsyn, men tar seg også av sikkerhetsspørsmål, hvis det skjer ulykker i verneområdene. Utdannelsen deres består av

I Vikingbukta nær Scoresbysund, Grønland, kan isbreene studeres på nært hold med gummibåt (foto: John Frikke).

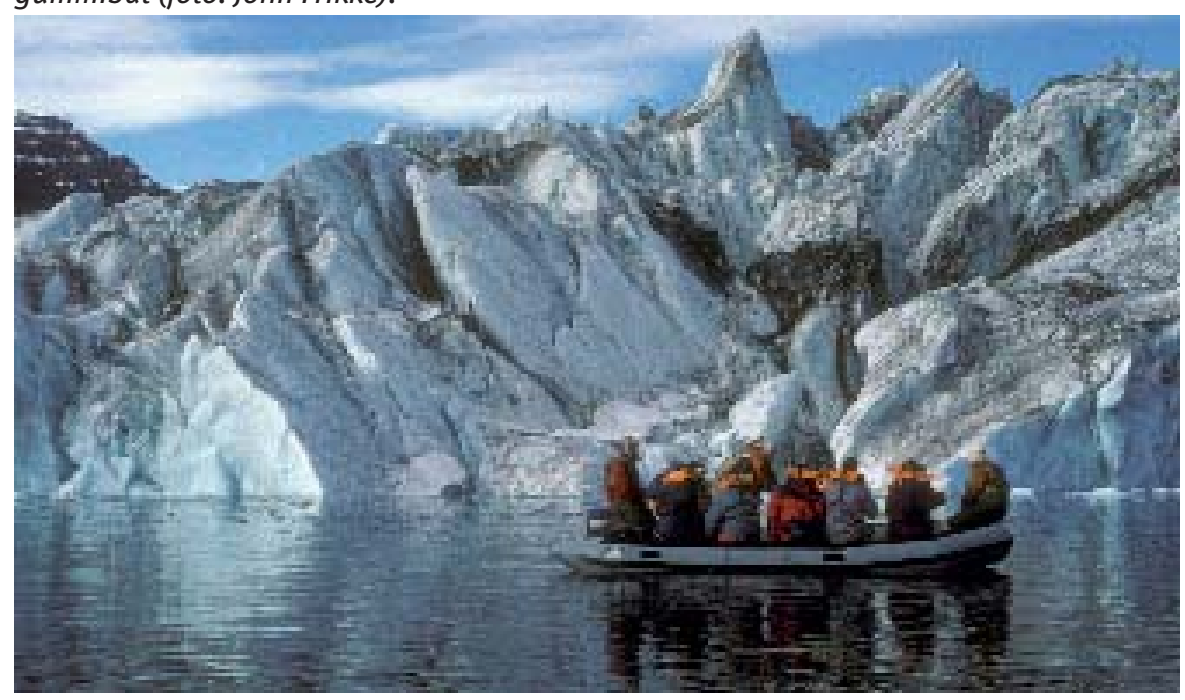




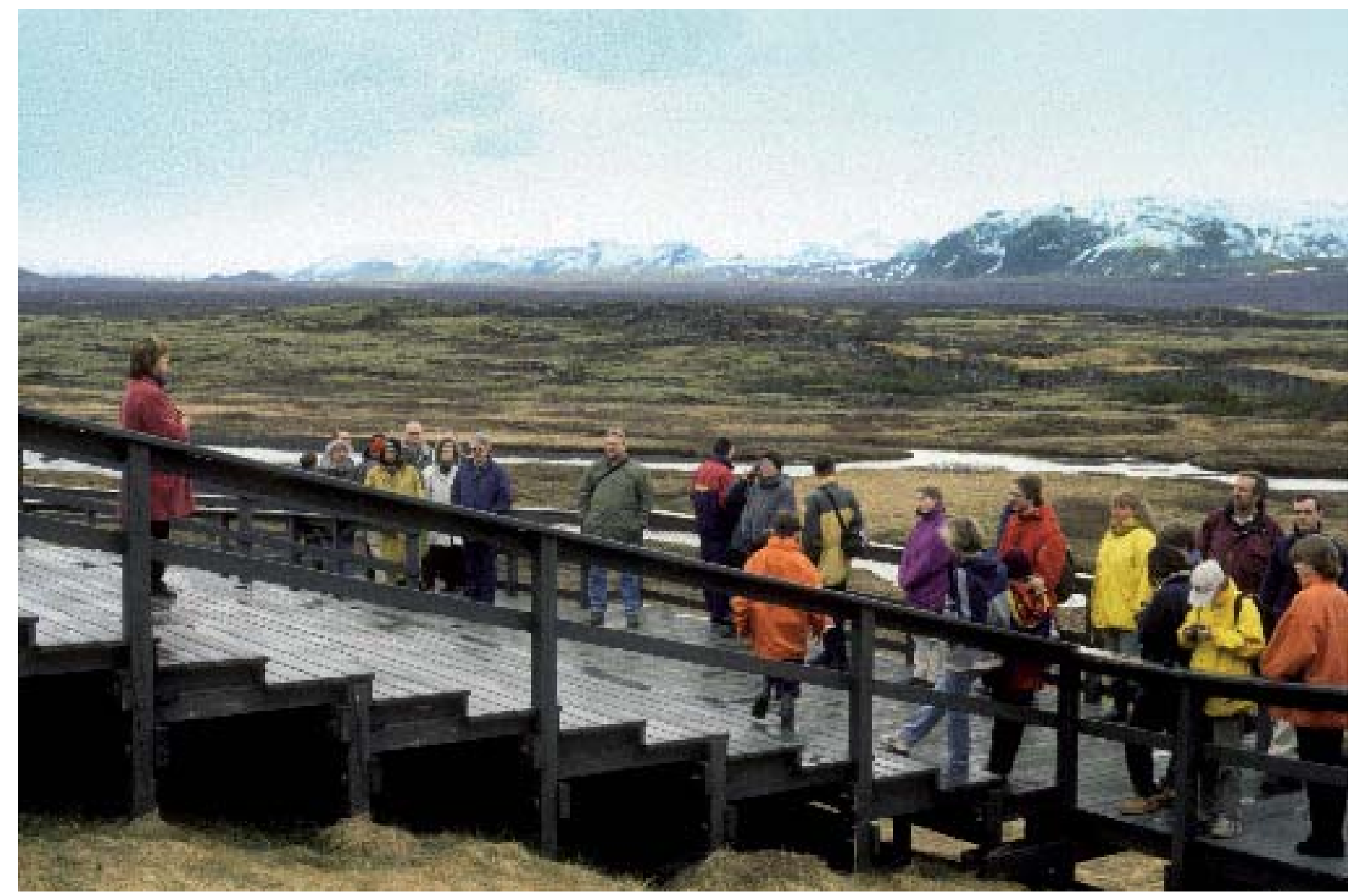

Formidling ved Thingvellir, Island (foto: John Frikke).

et 120 timers kurs som miljømyndighetene står for.

På Grønland har en naturveileder arbeidet i tre år i Nuuk med hovedvekt på prosjekter for barn og lærere i grunnskolen. De aller fleste prosjektene ble vellykkede, spesielt de prosjektene der barna var fysisk aktive i naturen i forbindelse med undervisningen. Ordningen videreføres derfor i Nuuk, og det er planer om å ansette naturveiledere i syv av Grønlands kommuner i 2006. Dessuten er det planer om å opprette en nasjonal utdannelse for naturveiledere. Naturveilederen i Nuuk har gjennomført den danske utdannelsen i regi av Skov- og Naturstyrelsen, som i alt varer 504 timer.
Svalbard har ingen egentlige naturveiledere, men til gjengjeld har de gode erfaringer med "Guide- og turlederopplæring", der bærekraftig adferd i forhold til natur og kulturminner inngår i utdannelsen på linje med sikkerhet og feltkunnskap. I 2006 åpner besøkssenteret "Svalbardporten" i Longyearbyen, der formidling av natur og kulturminner er et sentralt element i utstillingen.

Til tross for forskjeller i bruken av naturveiledning på Grønland, Island og Svalbard er det også fellestrekk. Av den grunn har ei prosjektgruppe under Nordisk Ministerråd utpekt tre områder, der naturveiledning bør videreutvikles i arktisk sammenheng.

\section{Utdannelse på høyt nivå}

Prosjektgruppa anbefaler at det opprettes en felles arktisk videreutdanning for naturveiledere, guider, oppsynspersoner og andre som tar med folk ut i naturen på Grønland, Island og Svalbard pluss de øvrige arktiske områdene i Norden. Utdannelsen skal supplere de nasjonale utdannelsene og sette kunnskap om arktisk natur, miljø og kultur inn i et globalt perspektiv. Nivået skal være høyt, og foreleserne skal være både forskere og praktisk utøvende.

Innen utgangen av 2007 bør det utarbeides et konkret forslag til utdannelsens innhold, struktur og finansiering som Nordisk Ministerråd kan ta stilling til. 


\section{Informasjon på internett} Gruppa anbefaler dessuten opprettelse av en web-basert informasjonskanal for naturveiledere i Arktis, der nasjonale erfaringer med naturveiledning og naturformidling kan registreres og videreformidles. Samtidig bør det undersøkes om det er basis for et permanent forum for utveksling av erfaringer med naturveiledere i Arktis.

\section{Arktisk naturdag}

En siste anbefaling er at det opprettes en årlig arktisk naturdag

Ei gruppe turister beundrer oppsprukne klippeformasjoner på Island (foto: Jens Muff Hansen/Naturplan).

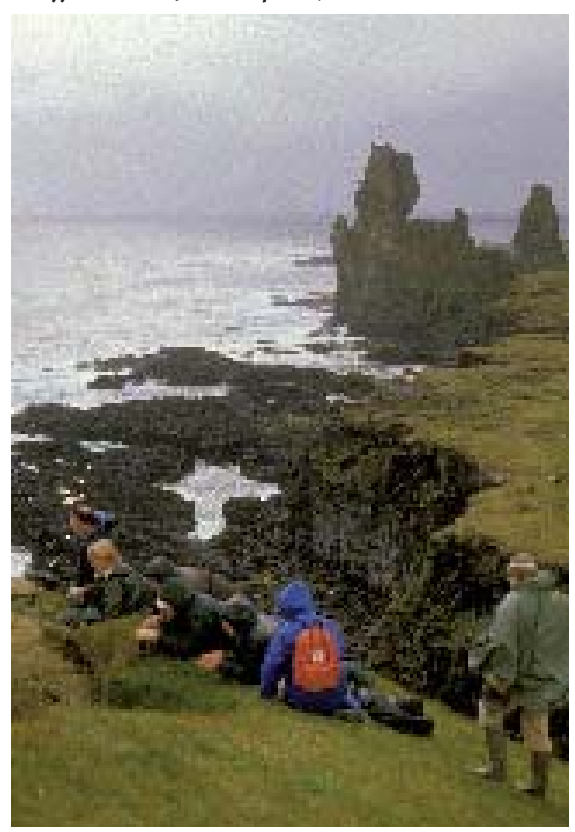

\section{Håndbok for naturveiledere}

Hva er god naturveiledning i Arktis, og hvordan gjør man formidlingen levende og interessant? Naturveiledere og guider kan nå hente inspirasjon i et utkast til en håndbok "Naturen er din arbeidsplass", som kan lastes ned på www.norden.org. Der påpekes det at god naturveiledning knytter formidling av kunnskap til folks følelser, fornemmelser og opplevelser i naturen.

Håndboka inneholder også mange nyttige tips. Et av dem er å være så godt forberedt og ha god kjennskap til området man skal fortelle om, slik at man har overskudd til å være spontan. Hvis en ørn plutselig flyr over himmelen, skal opplevelsen gripes og brukes, selv om naturveilederen egentlig hadde planlagt å snakke om noe annet. Et annet godt råd er å fortelle historier istedenfor å servere tørre fakta. Et tredje råd er å skape diskusjon. Håndboka inneholder en rekke fakta, fortellinger og folkesagn om Grønland, Island og Svalbard som kan brukes for å gjøre naturformidlingen levende.

som skal synliggjøre det økologiske samspillet mellom Arktis og de tempererte delene av Norden. Det kan gjøres for eksempel gjennom arbeid med tema som mennesket i naturen, forurensning, næringskjeder, klima, vann og geologi. En mulighet er at skoleklasser i de nordiske landene arbeider med et fellesprosjekt om naturen i Arktis med avslutning og presentasjon av prosjektet på naturdagen. Dagen bør feires ved vårjevndøgn den 30. mars, ettersom sola spiller en avgjørende rolle for livsvilkårene i det høye nord.
Rapport: in press "Din arbetsplats är naturen. En handbok om naturvägledning för naturvårdare och guider i Arktis.".

Søk også etter rapporten/emnet på: www.norden.org/pub 


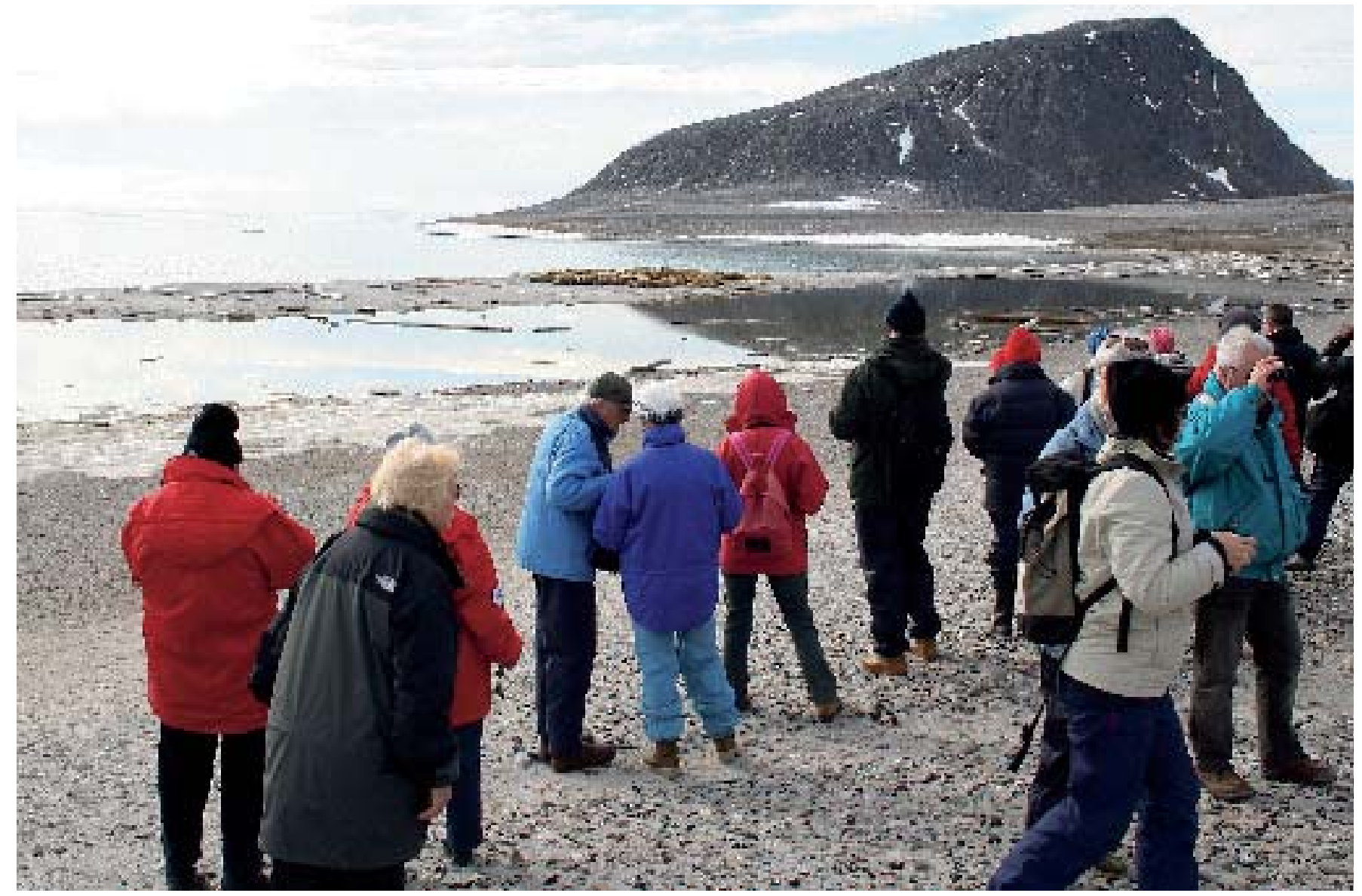

På Phippsøya, Svalbard, kan besøkende komme nært hvalrossene (foto: Marie Lier/Naturplan).

Turister på vei opp gjennom en dal ved Kap Stewart, Grønland (foto: John Frikke).

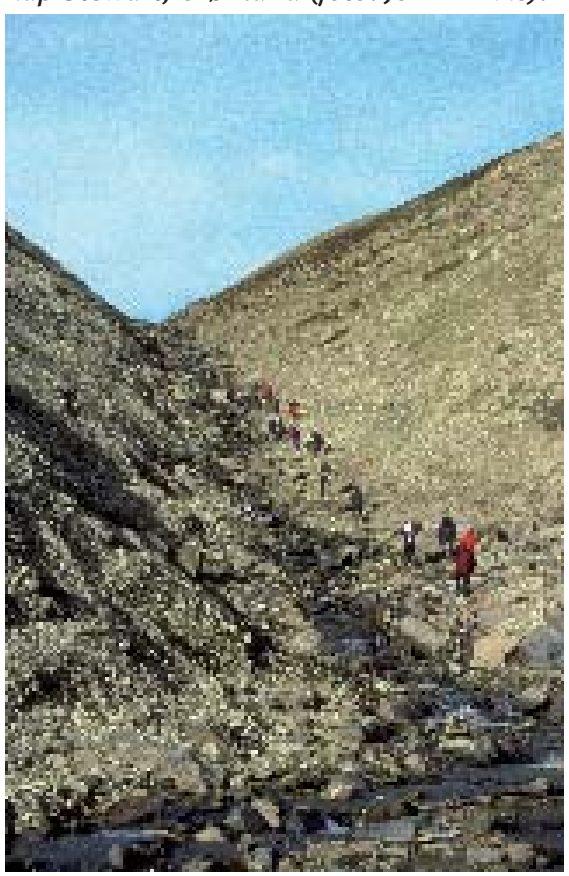




\section{Miljøundervisning skaper miljøbevissthet}

Undervisning, der det arktiske miljøet og menneskets samspill med naturen inngår, er en god investering $i$ framtiden, hvis dette fører til at barna vokser opp med en større miljøbevissthet enn tidligere generasjoner. Pilotprosjektet på Grønland, Island og Svalbard er en god start.

Tre grunnskoler på Grønland, to på Island og en på Svalbard har medvirket i pilotprosjektet "Miljøundervisning i Arktis". Målet var å skape samarbeid mellom de ulike landene og bevisstgjøre barna om naturen og kulturminnene.

Miljø ble definert som "menneskets samspill med naturen til alle tider", og emnet "Hval og hvalfangst" var utgangspunkt for et tverrfaglig skoleprosjekt, der fag som natur og miljø, historie, samfunnsfag og kreative fag ble dratt inn.

11 lærere og 200 elever deltok i prosjektet. Engasjementet var stort, og det ble gjennomført mange vellykkede undervisningsopplegg i de enkelte landene

Barn fra Kangillinnguit smaker på selkjøtt (foto: Isaavaraq Petrussen).

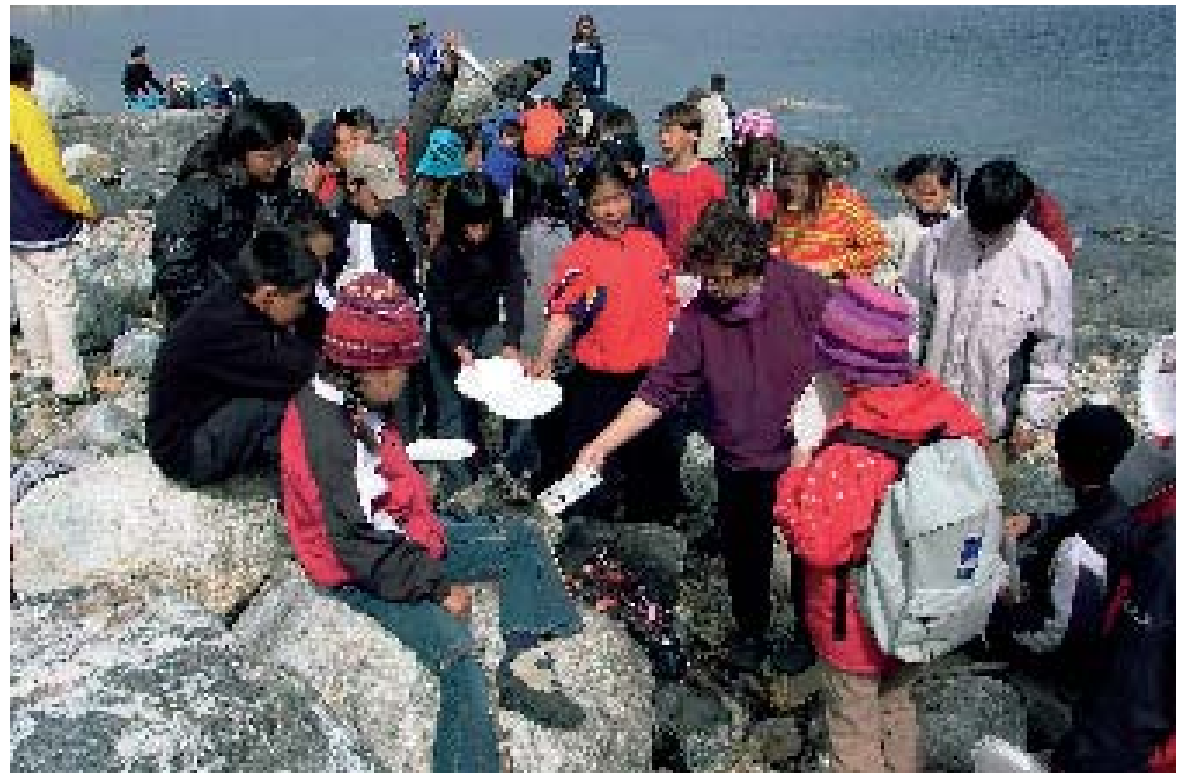




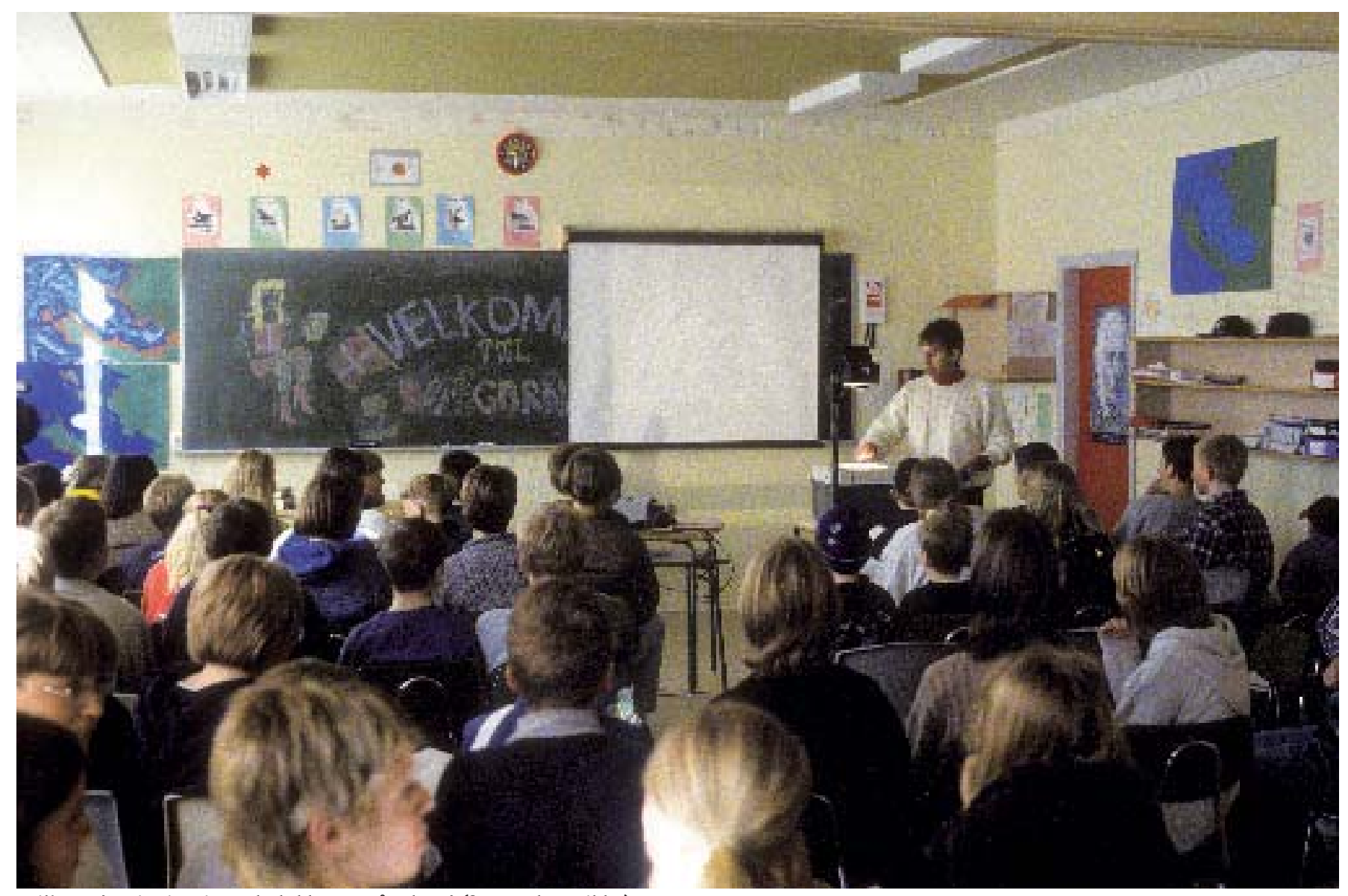

Miljøundervisning i en skoleklasse på Island (foto: John Frikke).

der elevene undersøkte sitt eget lands kultur- og naturhistoriske tilknytning til hvalfangst. Skolene oppnådde dog ikke å etablere den ønskede interregionale kontakten som skulle gi elevene en forståelse av forskjeller og likheter i hvalfangstens historie på Grønland, Island og Svalbard.

På bakgrunn av pilotprosjektet legger arbeidsgruppa fram en rekke anbefalinger som skal styrke det interregionale samarbeidet i framtidige skoleprosjekter i Arktis. Før det tas kontakt med skolene, bør det skrives en manual om prosjektforløpet med alle relevante opplysninger om mål, innhold, rettigheter og økonomiske rammer. For å sikre den faglige kvaliteten og lette lærernes arbeid, bør det utarbeides undervisningspakker. Det vil også være nyttig å sette av penger til et innledende seminar, der lærerne kan møtes, for å knytte personlige kontakter og finne samarbeidspartnere i de andre regionene. De økonomiske rammene bør være slik at skolene ikke får ekstrautgifter ved å delta på slike nordiske prosjekter, og slik at lærerne kan få en kompensasjon for det ekstra arbeidet.

Framtidige skoleprosjekt bør strekke seg over to år, der det første brukes til organisering og etablering av kontakter lærerne imellom. Prosjektene bør omfatte flere skoler enn pilotprosjektet gjorde, også videregående skoler, og man bør arbeide mot et felles resultat, for eksempel en hjemmeside. Det vil styrke samarbeidet og tydeliggjøre at dette er en felles nordisk satsning.

Rapport: TemaNord 2003:538

"Miljøundervisning i Arktis"

www.norden.org/pub/sk/

showpub.asp?pubnr=2003:538.

Søk også etter rapporten/emnet på: www.norden.org/pub 


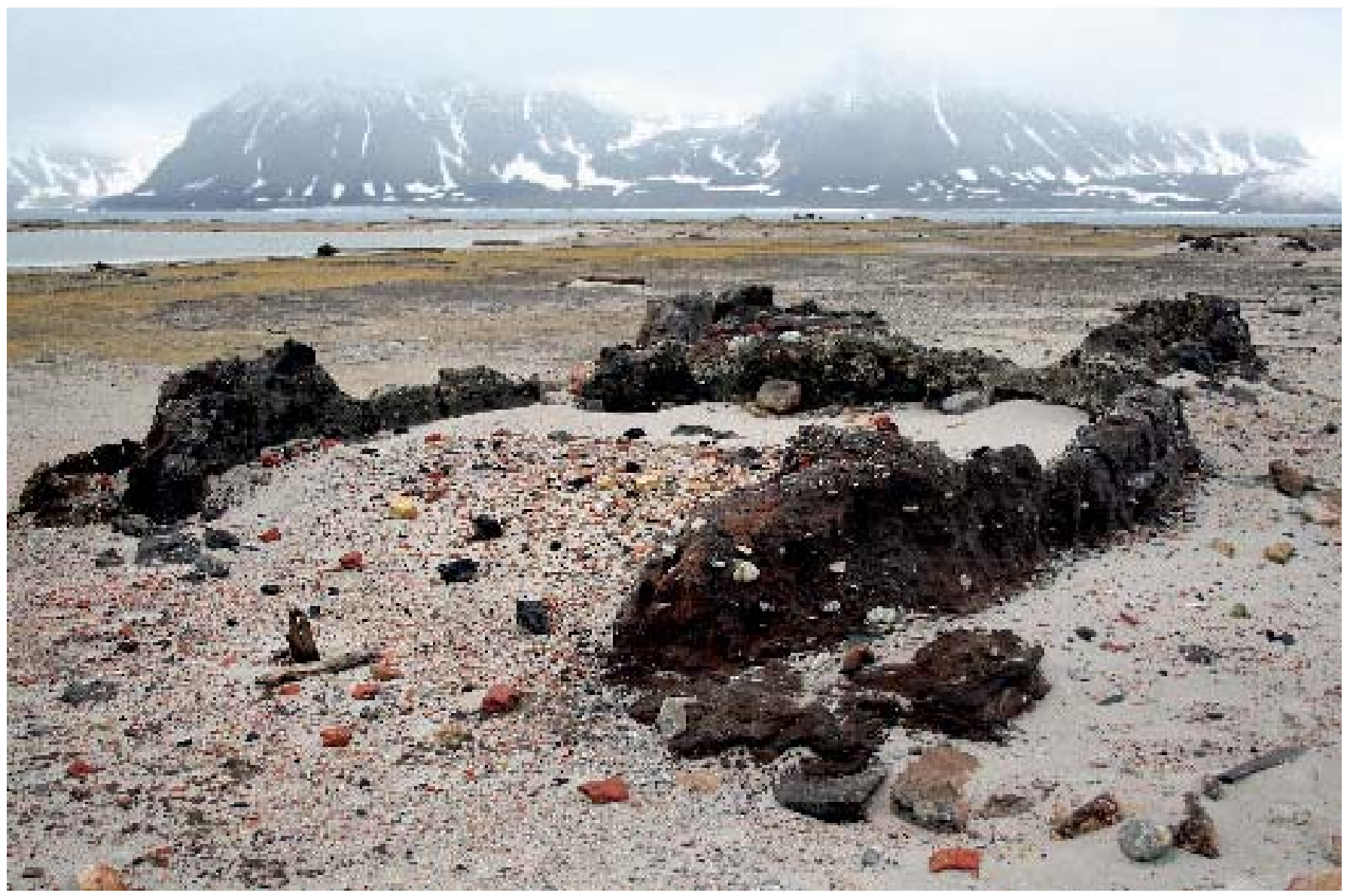

Rester av en spekkovn fra hvalfangsttida, Smeerenburg på Svalbard (foto: Marie Lier/Naturplan).

\section{Et glimt fra hvalfangstens historie}

På 1600-tallet begynte hvalfangere fra Europa og Amerika å fange hval rundt Grønland, Island og Svalbard. Ved Island ble bestandene, først av de store bardehvalene og senere de mindre hvalene, redusert drastisk i de følgende århundrene. All kommersiell hvalfangst har vært innstilt siden 1986.

På Grønland kulminerte hvalfangsten i det 16. århundre, da den storstilte europeiske hvalfangsten sto i sterk kontrast til inuittenes måte å fange hval på fra havkajakkene. Fangst av hvithval og narhval har stadig stor betydning på Nordvestgrønland.

Hvalfangsten ved Svalbard ga stort utbytte i starten, og det førte til uenigheter om rettighetene til fangstfeltene. I den første perioden ble det kokt tran av hvalspekket på land. Mange av ovnene og kokekarene ble stående igjen, og er i dag kulturminner. 


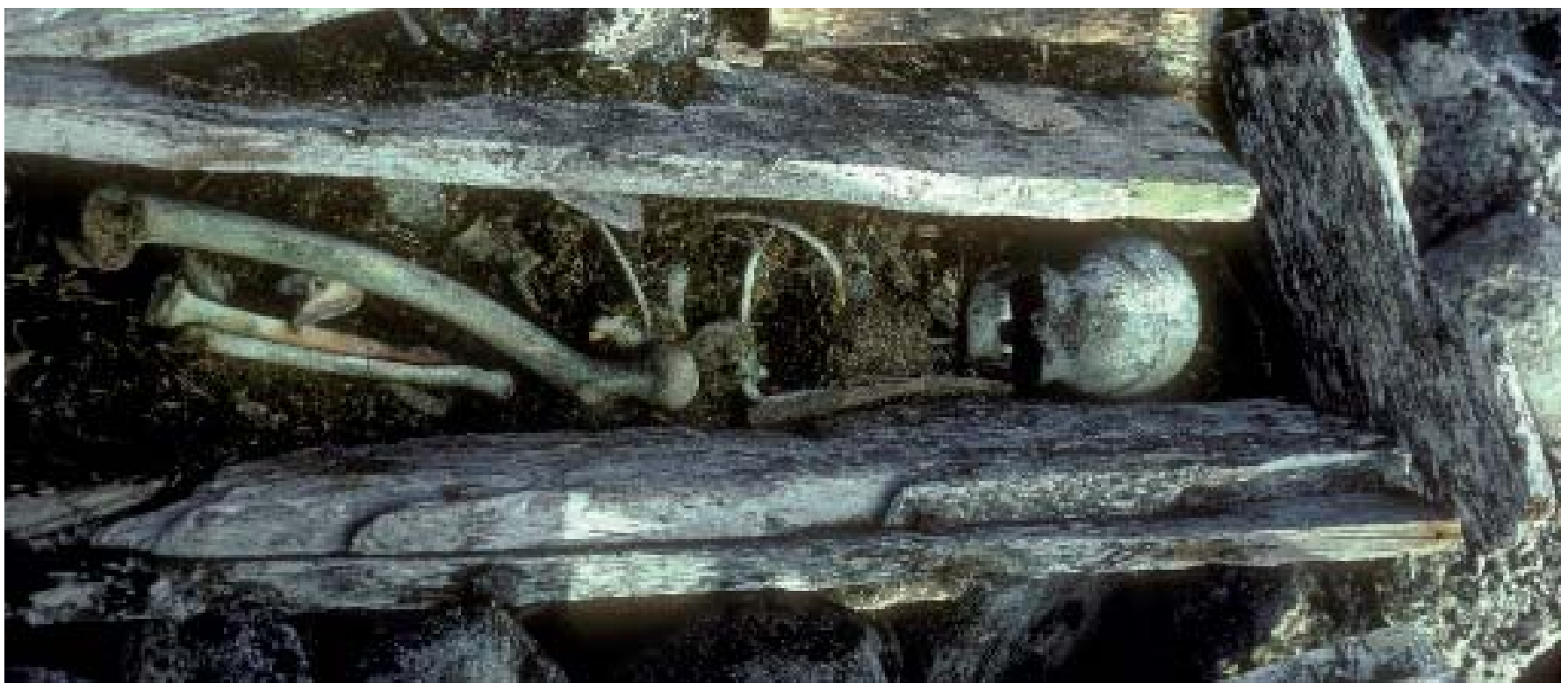

Gammel hvalfangergrav, Svalbard (foto: John Frikke).

\section{Tre skolers erfaringer}

Ukaliussuaq skole, Nuuk, Grønland: Ei 9. klasse brukte 30 timer på prosjektet som satte fokus på hvalenes biologi. Et av resultatene var plakatutstilling i gangene på skolen. Elevene fant opplysninger på internett og i bøker, og de besøkte naturveilederen i Nuuk, der de lærte mye nytt om hval på Grønland.

Klassa hadde kontakt med ei klasse på Island og ei på Svalbard, men det ble ikke etablert noe egentlig samarbeid. Læreren mener at et prosjekt som dette bidrar til barnas utvikling, men hun påpeker at IT-forhold hindret etablering av en god kontakt med elevene i de andre landene.

Grunnskólinn, Neskaupsstad, Island: Ei 6. og 7. klasse deltok i prosjektet. Prosjektet var organisert som ei temauke, der den vanlige timeplanen var erstattet med et tverrfaglig samarbeid mellom alle fagene. Skolen fikk besøk av en historielærer og borgermester med mye kunnskap om islandsk hvalfangst gjennom tidene. Prosjektet resulterte i en utstilling der elevene hadde sydd hvaler og fisk, lagd plakater og bygget en hvalfangststasjon i leire. Elevene hadde kontakt med en annen islandsk skole og en skole på Svalbard. Lærerne var glade for at de hadde fått temaet på forhånd, men de anbefaler at det utarbeides en undervisningspakke for framtidige prosjekter. De savnet også faste lærerkontakter på andre skoler før prosjektet startet opp.

Longyearbyen skole, Svalbard: Ei 5., 6. og 7. klasse deltok. Alle tre klassene hadde Svalbards kulturminnekonsulent på bes $ø$ k. Hun holdt foredrag og viste bilder om hvalfangsttida på Svalbard. Elevene besøkte også museet. De fikk god veiledning på biblioteket, og gode IT-forhold gjorde at de lett fikk tilgang på opplysninger på internett. Det var bare sporadisk kontakt med klassene på Island og Grønland. En av lærerne ga uttrykk for at før prosjektet starter, bør det etableres kontakt med ei fast samarbeidsklasse.

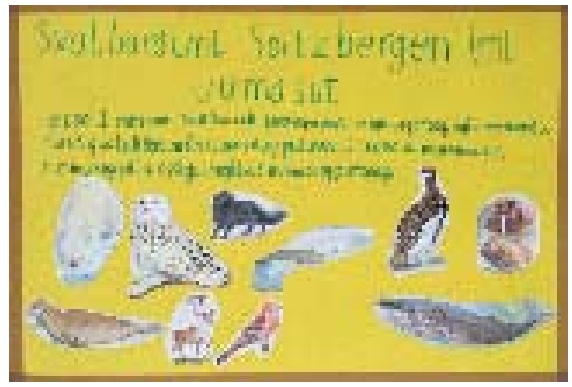




\section{Lokal Agenda 21 i Arktis}

Tre kommuner, Isafjördur på Island, Sisimiut på Grønland, og Longyearbyen på Svalbard har arbeidet med å realisere FNs Agenda 21 som skal fremme bærekraftig utvikling i samarbeid med innbyggerne, næringslivet og lokale organisasjoner.

Agenda 21 er et handlingsprogram som ble vedtatt på FNs verdenskonferanse for miljø og utvikling i Rio 1992, og som deretter ble bekreftet på miljøtoppmøtet i Johannesburg i 2002. I Rio fikk hvert enkelt samfunn i verden i oppgave å utarbeide handlingsplaner med konkrete tiltak for å fremme en bærekraftig utvikling i det 21. århundre. På lokalt plan er kommunene ansvarlige, men handlingsplanen bør utarbeides i samarbeid med innbyggerne, næringslivet og lokale organisasjoner, fordi Agenda 21 legger vekt på den alminnelige borgers ansvar for å ta vare på miljøet.

Nordisk Ministerråd har bidratt med 900000 DKK i økonomisk støtte til Lokal Agenda-prosjekter i Arktis. Dette har resultert i at det

Hus i Sisimiut. De fleste husene er bygd på klipper. Derfor er det ikke så lett å grave ned ledninger til vann og avløp (foto: Stefán Gíslason).

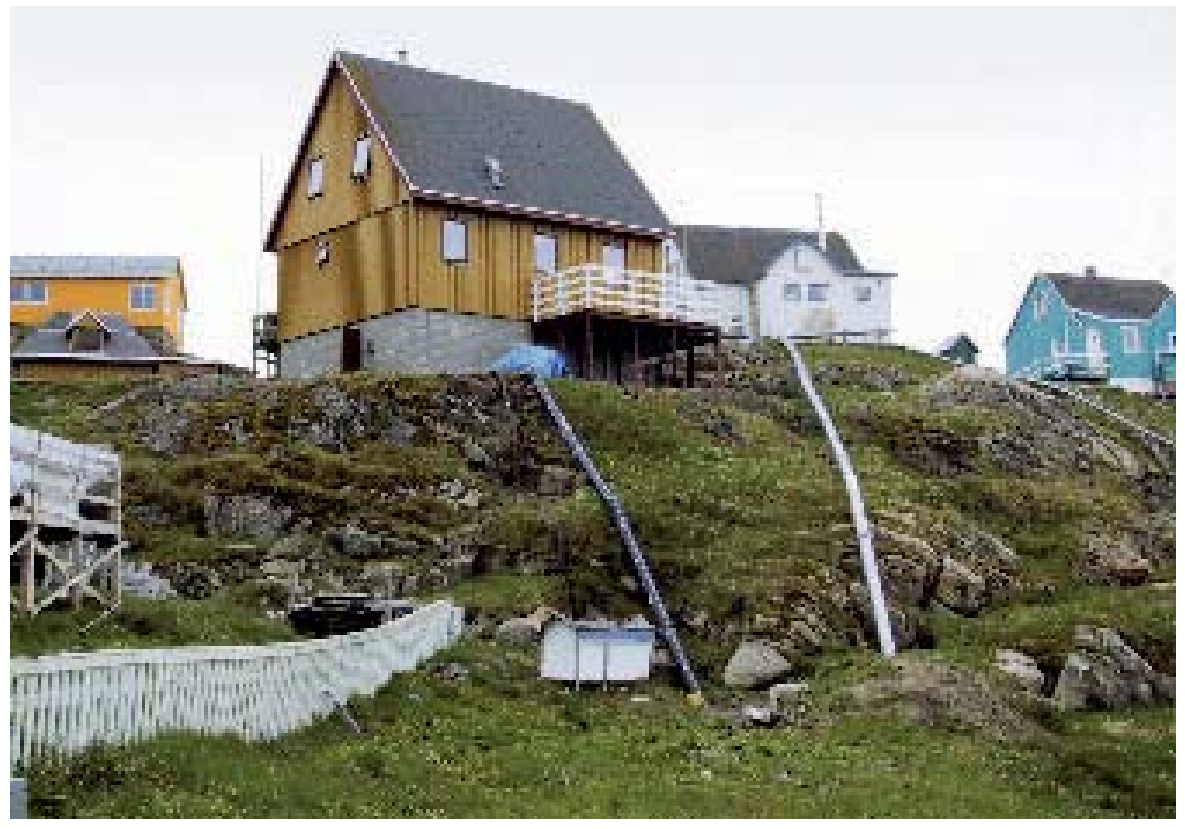




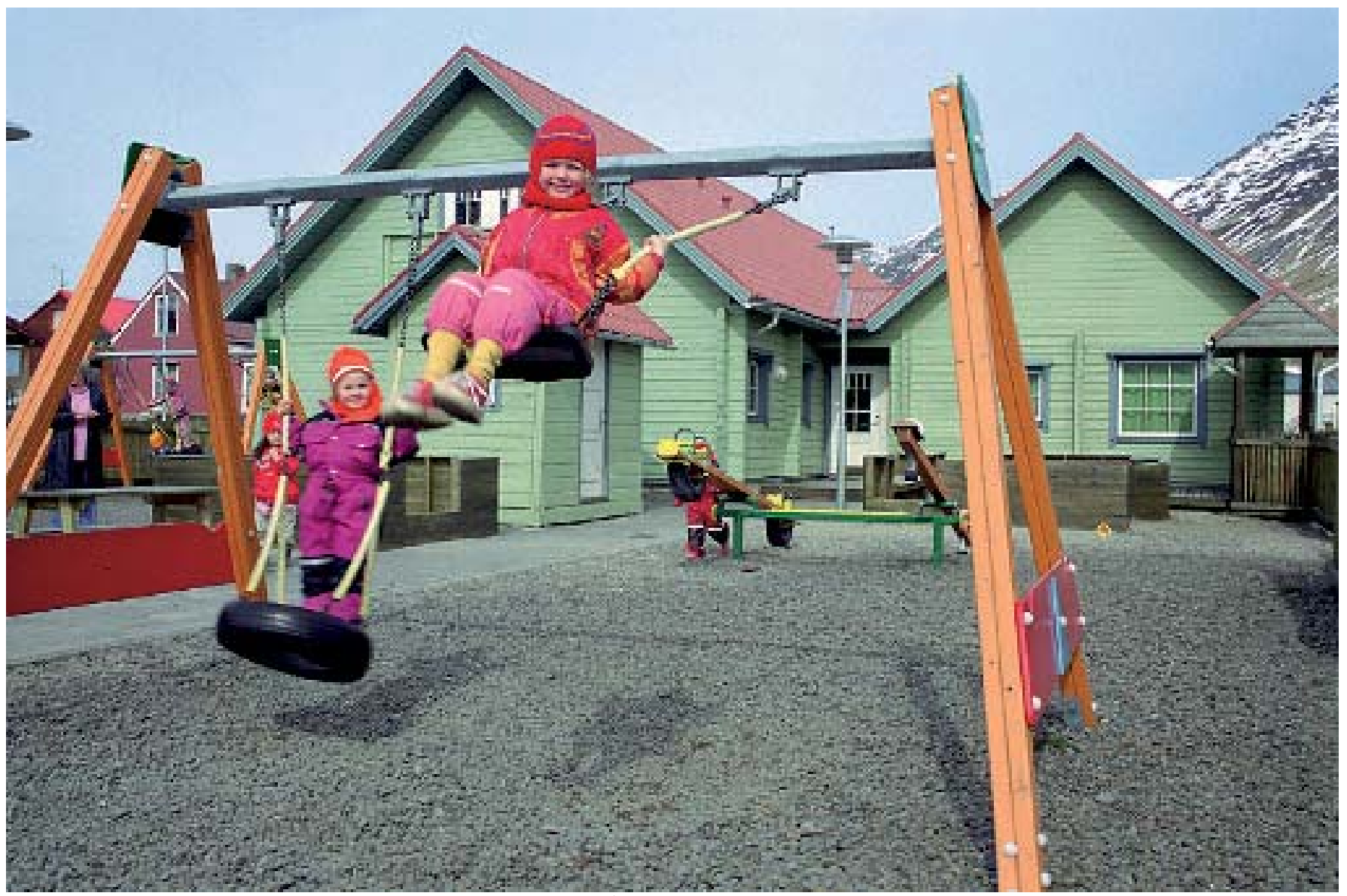

Barn i barnehage, Flateyri, Isafjordur kommune (foto: Rúnar Óli Karlsson).

har blitt satt i gang prosjekter i kommunene Isafjördur på Island, Sisimiut på Grønland, og Longyearbyen på Svalbard.

Isafjördur og Sisimiut er tradisjonelle fiskesamfunn, og begge har 4000-6000 innbyggere. Longyearbyen har 1500-1600 innbyggere, og gruvedrift er hovednæringen. Det er mulig å ta videreutdanning i alle tre byene. I Isafjördur finnes Center for Voksen- og Fjernundervisning, i Sisimiut ligger Artisk Teknologisk Center, og i Longyearbyen finnes Universitetssenteret på Svalbard, UNIS. Alle tre kommunene mener det er avgjørende at utdanningstilbudet forbedres for å hindre fraflytting og for å skape et allsidig næringsliv.
Dessuten satser kommunene på å fremme turistnæringen.

Selv om forholdene er forskjellige, er utnyttelse av naturressursene viktig for bosetningen i alle tre kommunene. Den storslåtte naturen og lokalsamfunnenes særegne kultur tiltrekker et økende antall turister. Naturen og kulturen er kommunenes styrke, men også deres svakhet. Fisken kan forsvinne, den arktiske naturen er sårbar, og folk kan flytte fra området, med det resultatet at kulturen går tapt. Det er med dette utgangspunktet man bør se på betydningen av å styrke den bærekraftige utviklingen gjennom Lokal Agenda 21-prosjekter

\section{Isafjördur}

Fiskebankene utenfor Isafjördur kommune er rike, og fiske og fiskeindustrien er de viktigste næringene. Byen Isafjördur er dessuten handels- og servicesenter for et stort område.

Isafjördur vokste etter 1788, da handelsmonopolet ble opphevet på Island. Det finnes mange kulturminner i kommunen som forteller om fortidens fiske, bl.a. gamle sjømannsleirer og fabrikkruiner. I kommunens statusrapport i forbindelse med Lokal Agenda 21 blir det lagt vekt på å katalogisere kulturminnene. Kulturturismen er i vekst, og kommunen har ansatt en person som både arbeider med turistspørsmål og med Lokal Agenda 


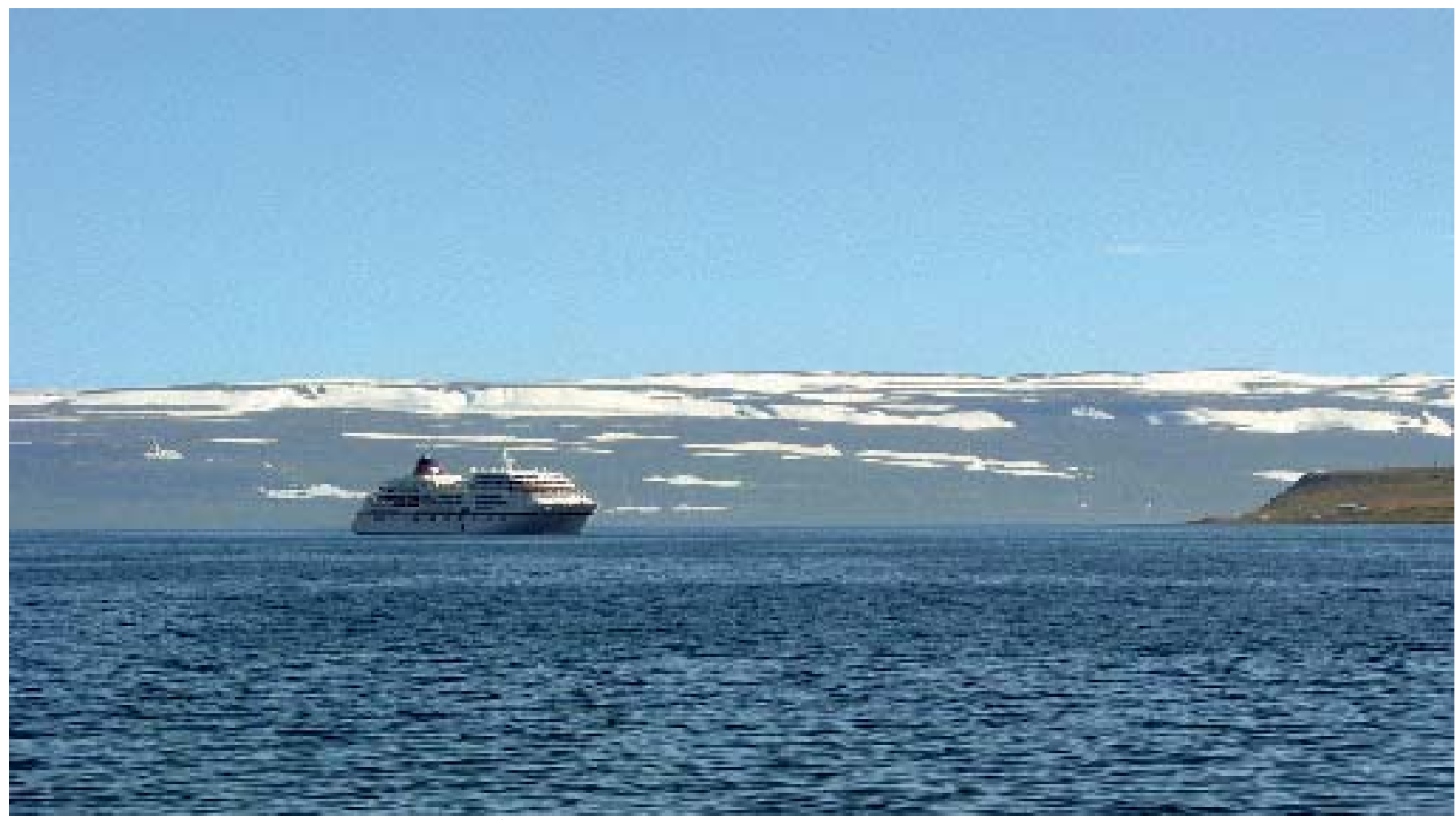

Passasjerskip utenfor Isafjordur (foto: Rúnar Óli Karlsson).

21 , noe som sikrer utveksling av informasjon mellom de to arbeidsfeltene.

Kommunens statusrapport tar for seg følgende tema: Forbruk og livsstil, forurensing av naturen, luft- og støyforurensning, naturvern, kulturminner, sykkel- og gangstier, drikkevannskvalitet, ressursutnyttelse, husholdningsavfall, offentlige innkjøp, næringsliv, energisparing og miljøundervisning i skolene. Det skal lages en handlingsplan som skal inneholde konkrete tiltak og klart definerte tidsfrister.

Innbyggernes deltagelse i det Lokale Agenda 21-arbeidet har vært begrenset, noe som sannsynligvis skyldes at forurensning hittil ikke har vært et stort problem lokalt. Kommunen har forsøkt å skape oppmerksomhet gjennom offent- lige foredrag, men interessen var liten. Erfaringene viser at det er bedre med foredrag på arbeidsplassene, i skolene og hos lokale foreninger.

\section{Sisimiut}

Sisimiut er Grønlands nordligste by med isfri havn om vinteren og den sørligste byen med hundesledekjøring. Fiske og fiskeindustri er de viktigste næringene. Dessuten spiller jakt på land- og havpattedyr en viktig rolle, samt at hundesledekjøring er en stor turistattraksjon.

Direktoratet for Miljø og Natur under Grønlands Hjemmestyre har hjulpet Sisimiut kommune med det Lokala Agenda 21-arbeidet. Arbeidet har ført til utarbeidelse av en statusrapport og et pilotprosjekt som omhandler "Lokal forvaltning av levende ressurser".
Bærekraftig bruk av de levende ressursene er et sentralt element i miljøpolitikken på Grønland.

\section{Longyearbyen}

Longyearbyen er den norske hovedbosetningen på Svalbard. Tradisjonelt sett er gruvedrift den viktigste næringen, og i dag utvinnes det kull sør for byen. I de seneste årene har offentlig virksomhet, forskning, utdanning og turisme skapt nye arbeidsplasser.

I Longyearbyen besto den Lokale Agenda 21-arbeidsgruppa av representanter fra Sysselmannen på Svalbard, Svalbardrådets samfunns- og kulturutvalg og Svalbard Samfunnsdrift A/S. Gruppa har gitt innspill til utarbeidelsen av en lokal samfunnsplan for byen og mener at arbeidet med Lokal Agenda 21 best videreføres gjen- 
nom de eksisterende lokalpolitiske prosessene.

Rapport: ANP 2005:702 "Lokal Agenda 21 i Arktis" www.norden.org/pub/sk/ showpub.asp? pubnr=2005:702.

Søk også etter rapporten/emnet på: www.norden.org/pub

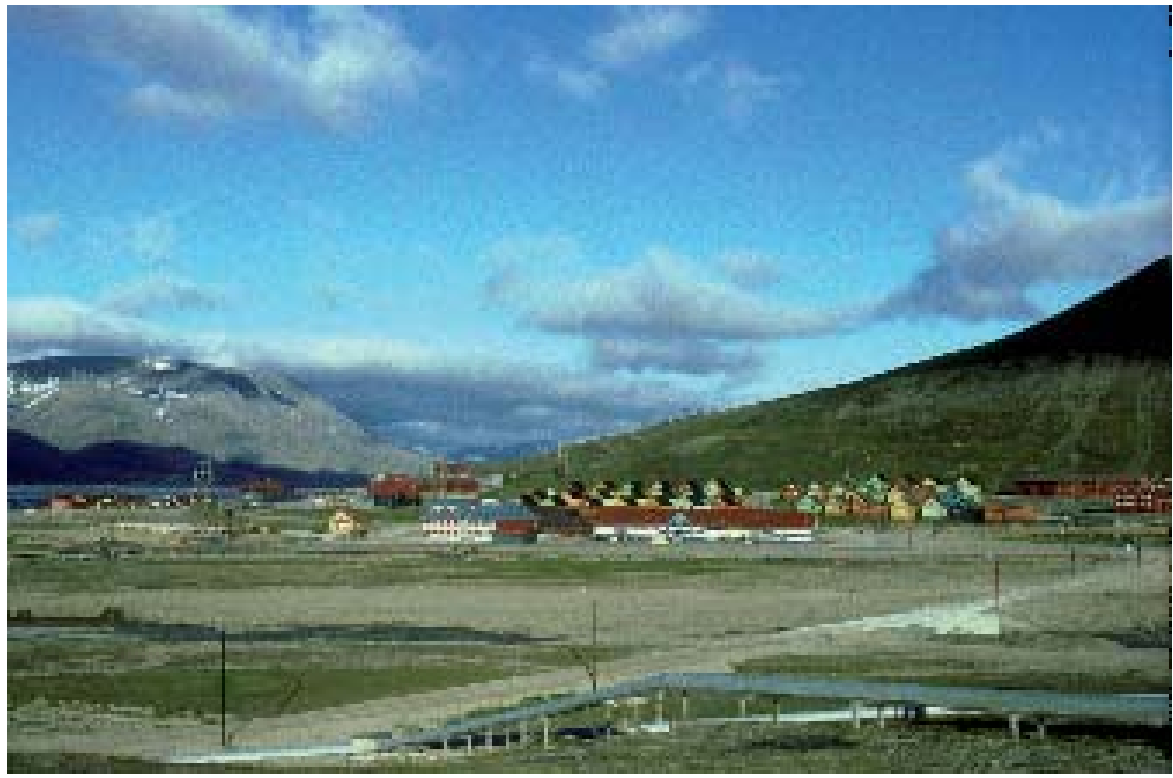

Longyearbyen - den norske havnebyen på Svalbard (foto: John Frikke).

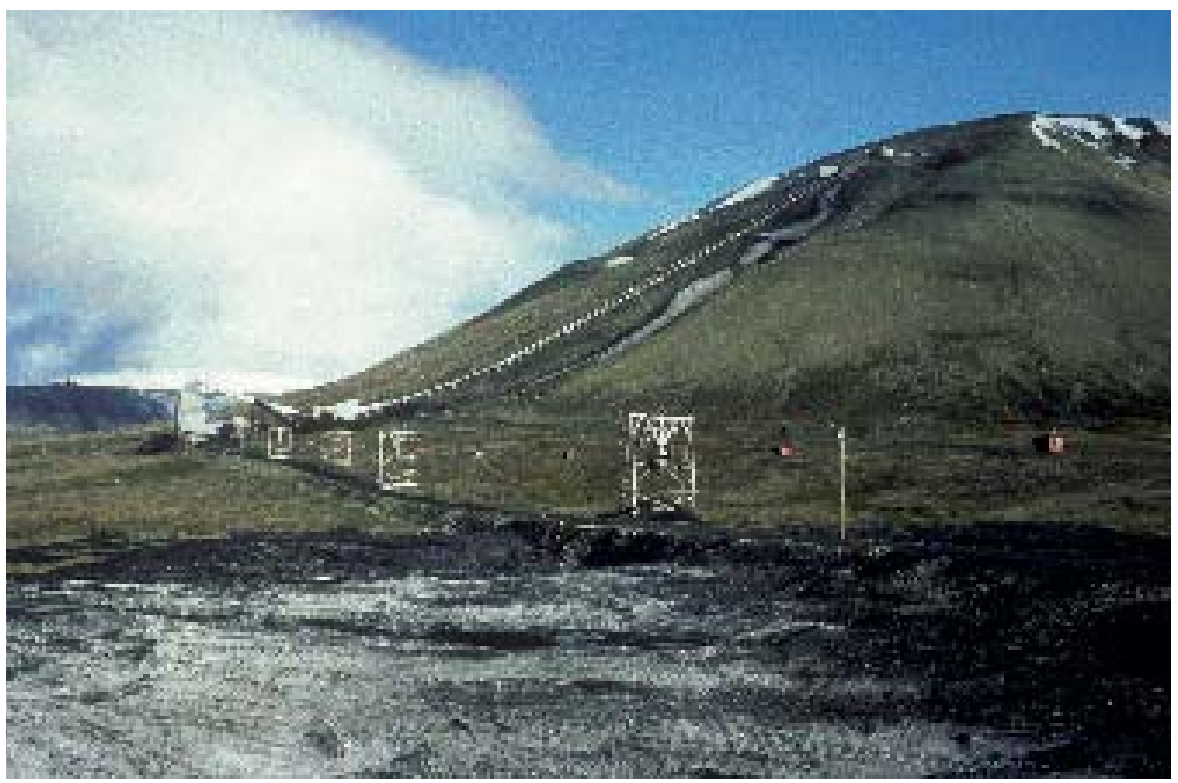

Den fredede taubana ved Longyearbyen (foto: John Frikke). 


\section{Pionerarbeid: Arktisk database over sjøfuglkolonier}

Databaser over sjøfuglkolonier er et verdifullt redskap for forskning, forvaltning og vern. Et nytt nordisk databaserformat kan bane vei for en cirkumpolar database over sjøfuglkolonier.

Sjøfuglenes hekkekolonier spiller en viktig rolle i naturen. De bidrar i seg selv til biodiversitet, men tiltrekker også rovdyr og åtseletere og skaper levesteder for en rekke andre dyr og planter. Koloniene spiller samtidig en sentral økologisk rolle ved deres transport av næringsstoffer og karbon fra havet til habitater på land. Mange steder i Arktis bidrar sjøfuglkoloniene også til menneskenes eksistensgrunnlag som matressurs og ved å skape muligheter for rekreative aktiviteter som turisme.

De store koloniene av hekkende sjøfugl $i$ de nordiske landene utgjør ofte en betydelig del av den totale bestanden, og de er sårbare ovenfor menneskeskapte forstyrrelser, endringer i habitatene, fiske og oljeleting. Det er derfor nødvendig å beskytte sjøfuglkoloniene ved en bærekraftig forvaltning.

I denne sammenhengen er databaser med informasjon om sjøfuglkoloniene et uunnværlig redskap. Formålet med databasene er

Lundefuglen er fortsatt tallrik i fuglefjellene på Færøyene (foto: John Frikke).

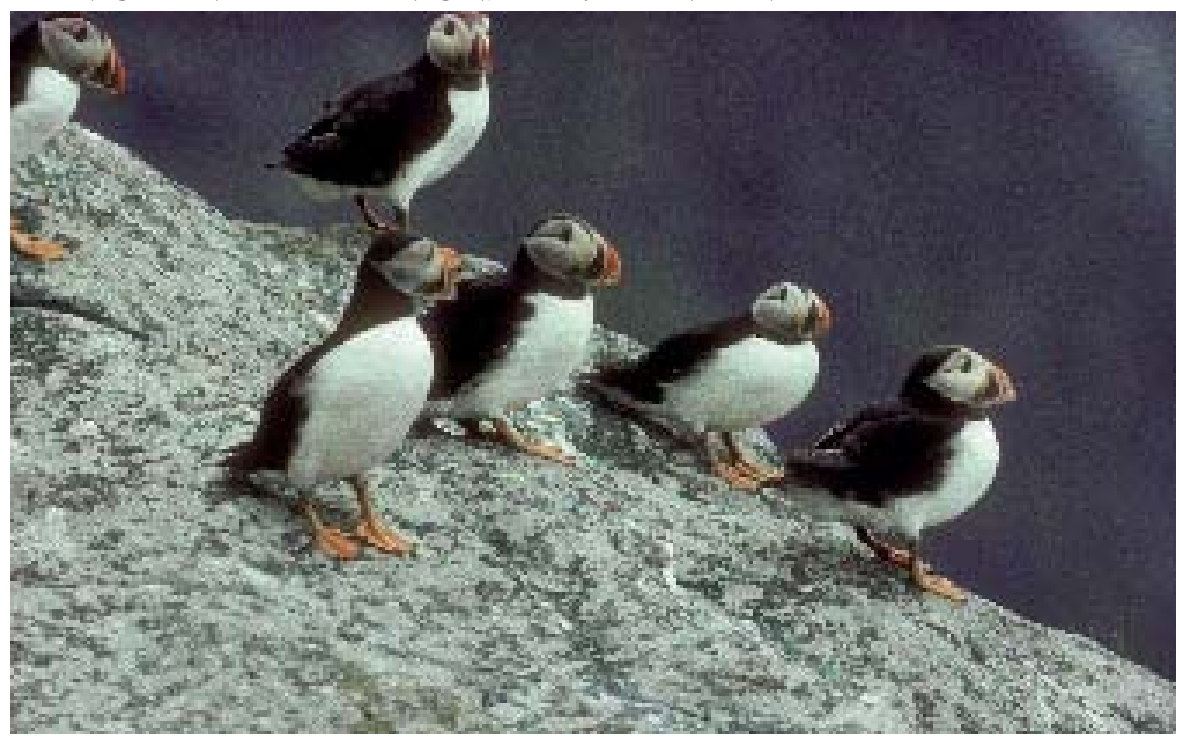




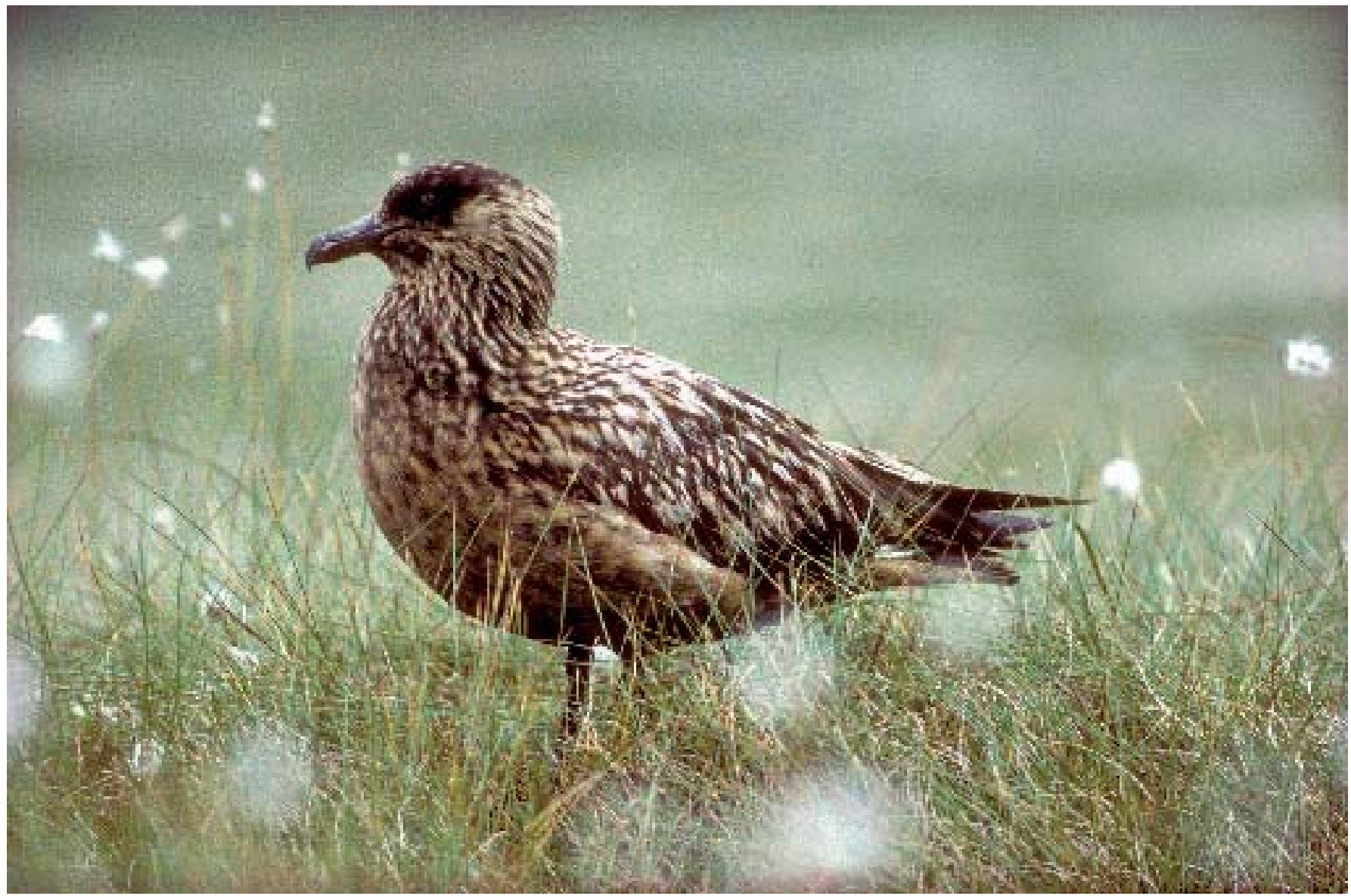

Sør på Island finnes en av verdens største kolonier av storjo (foto: John Frikke).

å samle inn og oppdatere informasjon om kolonienes beliggenhet, sammensetning og størrelse. Opplysningene er dermed tilgjengelige i forbindelse med forskning, forvaltning og vern. Databasene er derfor viktige for utvikling av strategier for bærekraftig bruk, lokalplanlegging, miljøvurderinger og overvåkning.

Et aktuelt eksempel er databasen over sjøfuglkolonier på Grønland som har vært nyttig ved vurdering av behovet for vern under planlegging av oljeleting langs den grønlandske vestkysten. Det er velkjent at sjøfugler er sårbare ovenfor oljesøl, og databasen gjorde det mulig å peke ut områder med stort behov for vern, slik at skadevirkninger, som følge av oljeleting, kunne minimeres eller motvirkes.

Samordna databaser over sjøfuglkolonier, som dekker hele det arktiske området, vil være særlig verdifulle. De skaper mulighet for analyser som omfatter større områder enn de enkelte lands territorier. Ei prosjektgruppe under Nordisk Ministerråd har nå tatt et stort skritt i riktig retning ved å utvikle et felles format for databaser over sjøfuglkolonier på Færøyene, Grønland, Island, Jan Mayen og Svalbard.

\section{Omfattende opplysninger}

Det nye databasesystemet inneholder omfattende opplysninger om sjøfuglkoloniene. De forskjellige kategoriene, som brukes for å beskrive koloniene, inkluderer beliggenhet, detaljert beskrivelse av vernestatus, eierforhold, tilstedeværelse av rovdyr, historiske kilder og data, referanser og opplysninger om hvor velegnet de enkelte koloniene er for å kunne fange inn fugler for ringmerking eller andre former for forskning. Databasen kan også oppdateres

Polarlomvi finnes i stort antall på Svalbard (foto: Marie Lier/Naturplan).

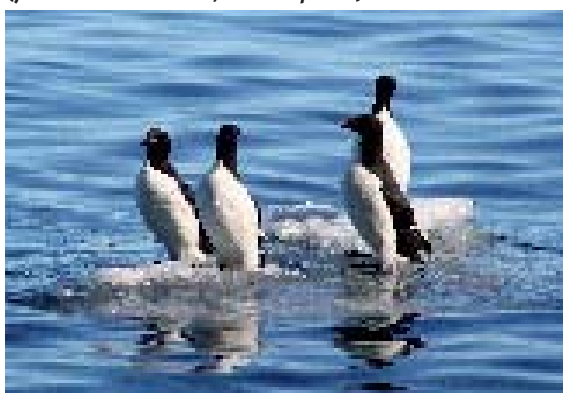


med detaljerte opplysninger om individuelle tellinger av enkeltarter i kolonien, hvem som har utført observasjonene og tellingenes nøyaktighet. Fotodokumentasjon kan inkluderes i databasen.

\section{Mål: En cirkumpolar standard.} Nordiske eksperter deltar i den Cirkumpolare sjøfuglgruppa under Arktisk Råd. Nylig har de foreslått å bruke deres databaseformat, som en felles standard i en cirkumpolar database som også omfatter de amerikanske, kanadiske og russiske delene av Arktis. Forslaget ble godt mottatt og har vakt stor interesse.

Tilsvarende det som er tilfelle i noen av de nordiske landene, har også andre arktiske land veletablerte databaser med informasjon om sjøfuglkolonier som både brukes i forbindelse med forskning og forvaltning. Under det nordiske databaseprosjektet, ble de fem landene enige om et standardisert format som tar hensyn til hvert lands nasjonale behov. Det er sannsynlig at det nordiske databaseformatet også kan dekke de fleste av USA, Canada og Russlands behov, selv om mindre justeringer og tilføyelser kan vise seg å være nødvendig. Det å ha felles beskrivelseskriterier for hele Arktis vil være et stort framskritt i forsøket på å få svar på viktige vitenskape-

\section{Sjøfuglene i Arktis}

Færøyene: Antall hekkende arter: 20. Antall kolonier: 1600. Antall hekkende par: 1,7 millioner. De viktigste overvåkningsprogrammene omfatter lomvi, krykkje og havsule.

Grønland: Antall hekkende arter: 21 . Antall kolonier: 3700 . Antall hekkende par: 39 milioner. Overvåkningsprogram er foreslått igangsatt for polarlomvi, ærfugl og rødnebbterne.

Island: Antall hekkende arter: 23. Antall kolonier: 7000. Antall hekkende par: Kanskje 7,5 millioner. To arter overvåkes på landsbasis: Storskarv og havsule. Ti arter overvåkes i utvalgte kolonier, mens 11 arter ikke omfattes av noe overvåkningsprogram.

Svalbard: Antall hekkende arter: 18. Antall kolonier: 1500. Antall hekkende par: Ca. 3 millioner. Sju arter overvåkes: Havhest, ærfugl, polarmåke, krykkje, lomvi, polarlomvi og alkekonge.

Jan Mayen: Antall hekkende arter: 15. Antall kolonier: 92. Antall hekkende par: 300.000. Ingen overvåkning.

lige, forvaltningsmessige og vernemessige interessante spørsmål når det gjelder sjøfuglkoloniene.

Rapport: TemaNord 2006:512

"Nordic Seabird Colony Databases". http://www.norden.org/pub/sk/ showpub.asp?pubnr=2006:512 Søk også etter rapporten/emnet på: www.norden.org/pub 


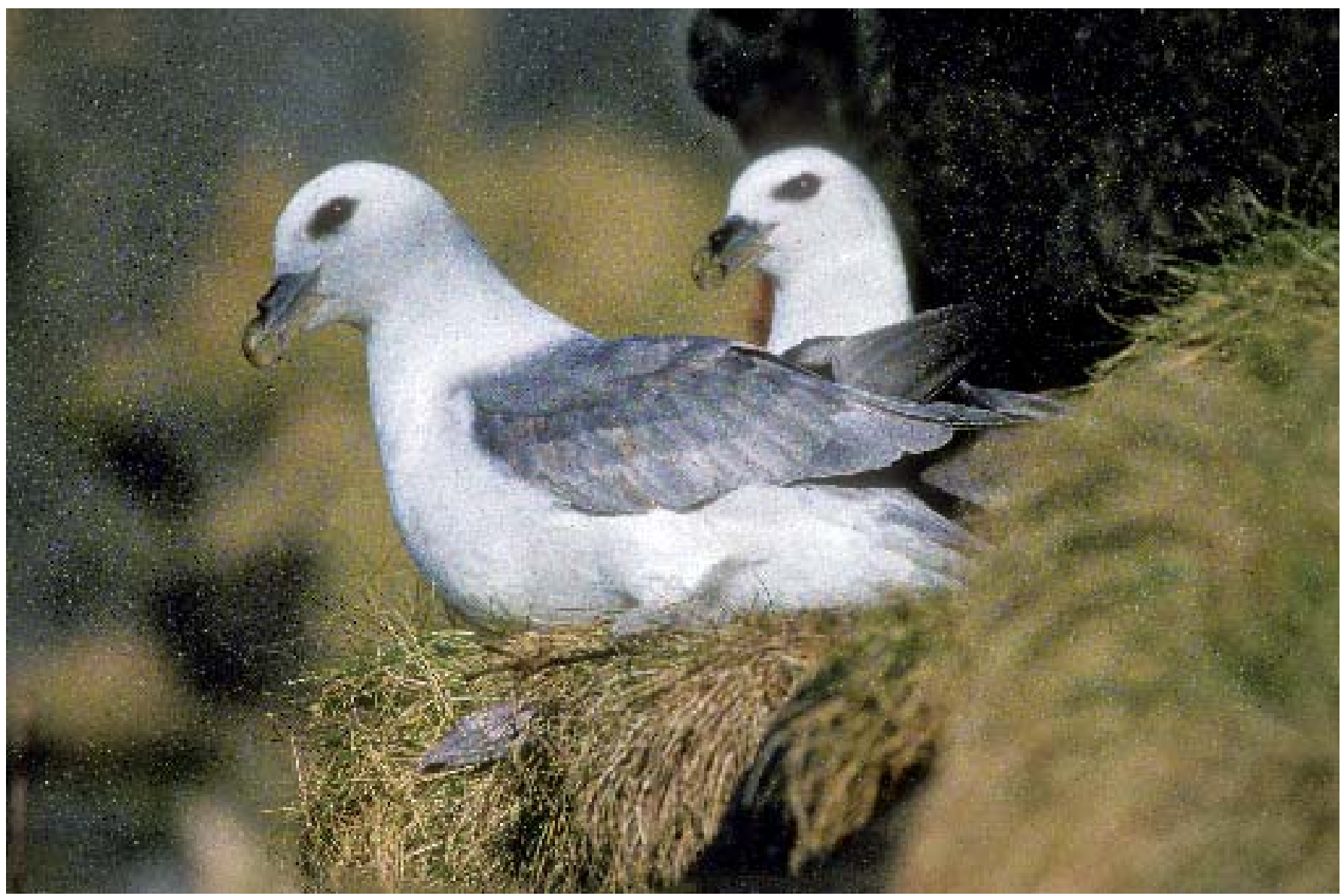

På Jan Mayen ruger havhesten i store kolonier (foto: John Frikke).

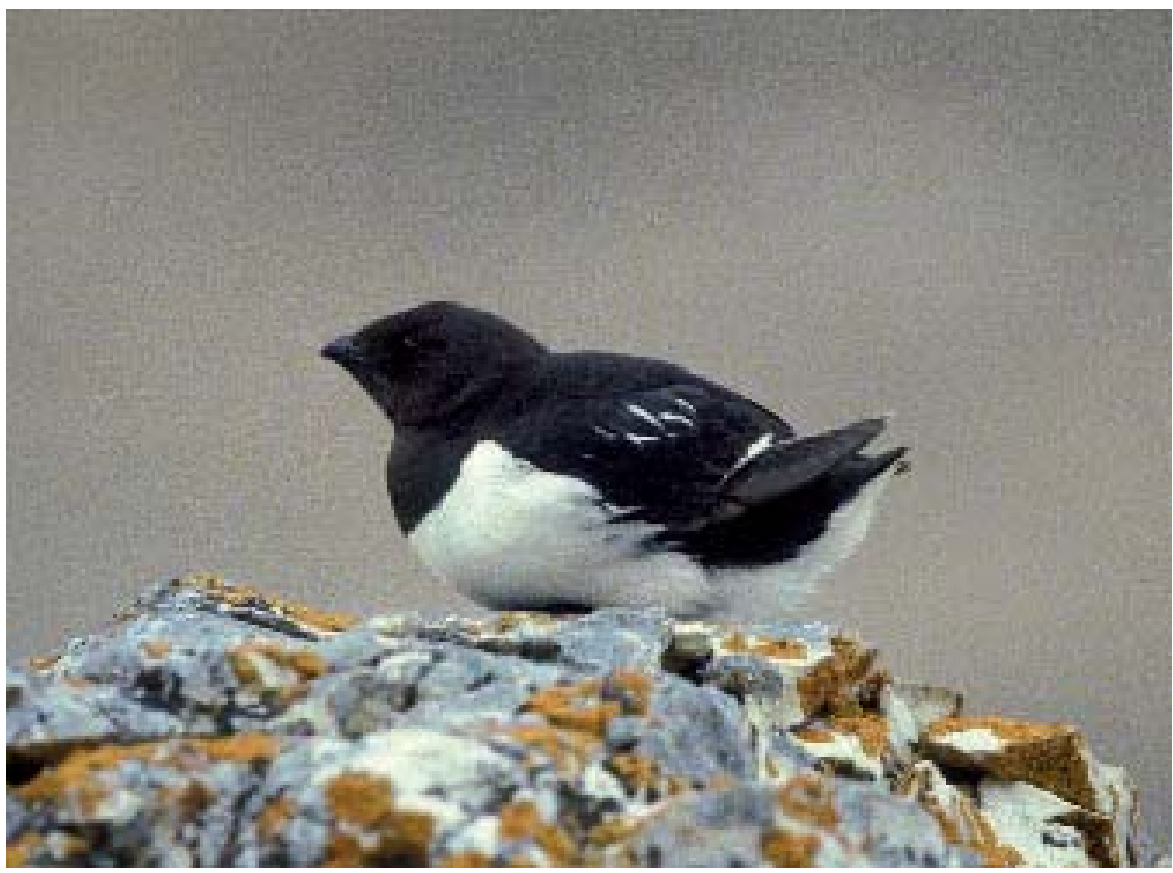

Alkekongen er tallrik mange steder på Grønland (foto: John Frikke). 


\section{Bunntråling og skraping av muslinger i Arktis: Sårbare habitater trenger beskyttelse}

\begin{abstract}
Bunntråling og bunnskraping kan øke dødeligheten til en rekke bunndyr og ødelegge koraller, svamper og arkeologiske funn på havbunnen. Sårbare habitater trenger øyeblikkelig beskyttelse.
\end{abstract}

Bunntrål og muslingskrape er to alminnelig anvendte fiskeredskap i Arktis. Bunntrål brukes til fangst av reker og fisk, og under trekket er de to tråldørene og bunnwiren i kontakt med havbunnen. Muslingskrape brukes til å skrape kamskjell, og de har en tung metallramme som skraper langs havbunnen.

De fleste fiskeartene og virvelløse dyrene på havbunnen lever i blanda samfunn, og unders $\varnothing$ kelser har vist at bunntråling og skraping av muslinger har sterk innvirkning på bunndyrene. Trål og muslingskrape er ikke særlig selektive, fordi fiskeredskapene er laget for å skape forstyrrelser på havbunnen, slik at bunndyrene fanges inn i nettet. Derfor risikerer alle dyrene i fiskeredskapenes bane og bli fanget, forflyttet, drept eller såret. På den måten øker bunntrålere og muslingskrapere dødeligheten til både de dyrene som er ønsket i fangsten, og de dyrene som ikke er det, skjønt dødeligheten varierer sterkt mel- lom ulike dyregrupper. Arter som blir relativt store, vokser sakte og er utvokst først etter mange år, er normalt mest sårbare. Dessuten, kan bunntråling redusere biodiversiteten, forstyrre forholdet mellom rovdyr og byttedyr, og skape langvarige endringer i artssammensetningen. Dette kan føre til dominans av arter som er særlig motstandsdyktige mot tråling.

Langvarige forandringer i dyresamfunnene på havbunnen kan oppstå selv om det bare er trålet på et sted i en relativt kort periode. I habitater med for eksempel dypvannskoraller, der flertallet av dyrene danner skjøre tredimensjonale strukturer, kan den aller første gangen det tråles forårsake alvorlige skader. Ved hvert enkelt trekk dekkes et areal på mellom en og to kvadratkilometer, slik at ganske få trekk er nok til å forstyrre samfunnet av bunndyr i et relativt stort område.

Tekniske forbedringer av redskapene og utvikling av større og bedre utstyrte fartøy muliggjør bunnfiske i nye områder, der det ofte lever sårbare organismer som tidligere var uttilgjengelige. Noen eksempler er bratte skråninger, områder med lava eller store steiner, og arealer som i de senere årene har blitt isfrie p.g.a. den globale oppvarmingen. 


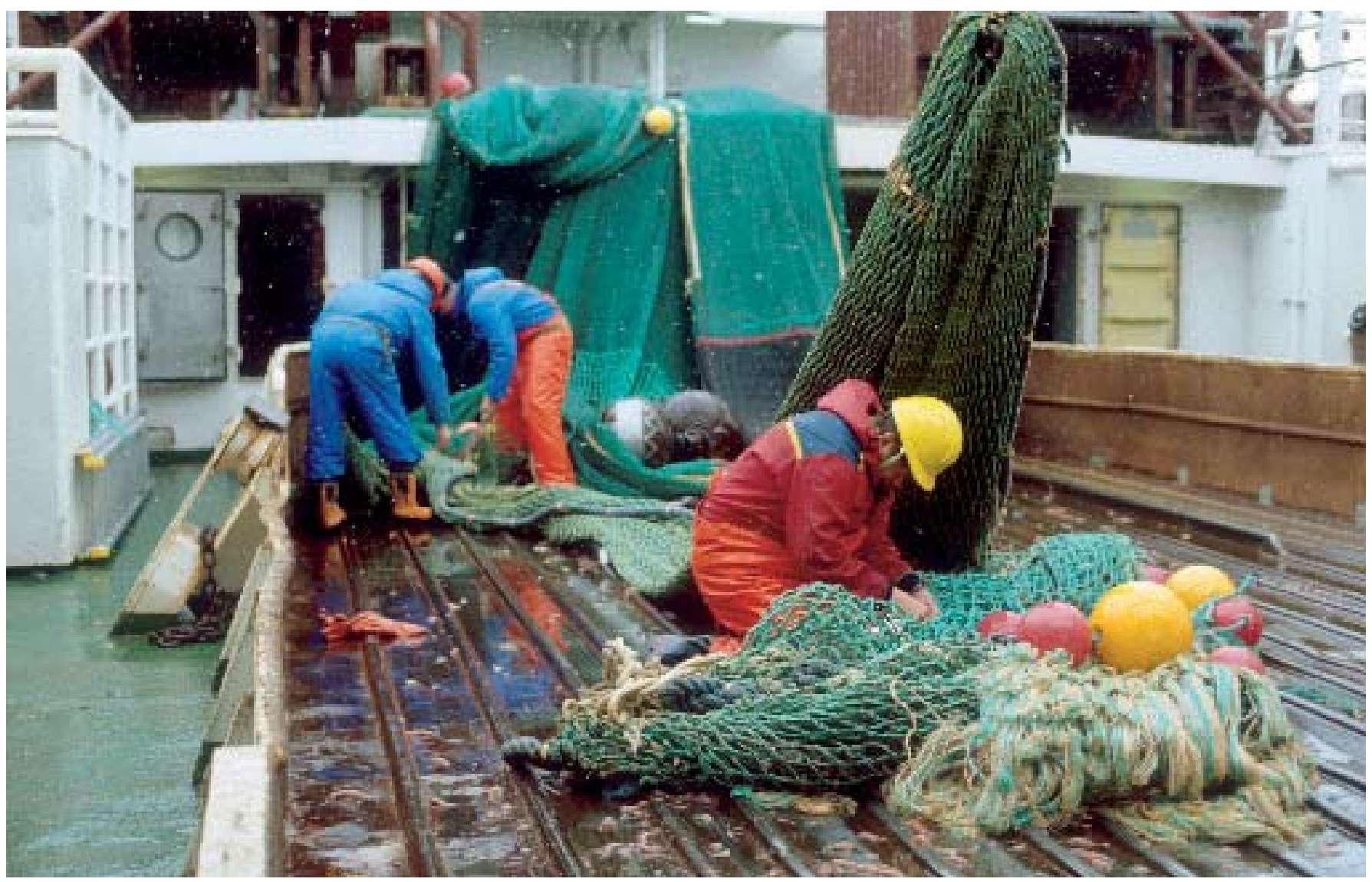

Reketrål renses på dekk (foto: Morten Rasmussen/Biofoto).

Den Nordiske Handlingsplanen understreker behovet for å undersøke effektene av bunntråling og skraping etter muslinger i havet mellom Grønland, Island, Svalbard og Jan Mayen. Havområdene utenfor Norges vestkyst, nord for $67^{\circ} \mathrm{N}$ og det norske territorialfarvannet i Barentshavet, er inkludert. Oppdagelsen av store korallrev utenfor norskekysten og det vedtatte vernet av dem, kan bli en hjørnestein i det videre arbeidet med å beskytte marine habitater, mens Barentshavet er et viktig økosystem som er utsatt for et voldsomt fiskeritrykk.

\section{Skraping av muslinger}

Skraping av kamskjell ved Island, Grønland og Norge startet etter oppdagelsen av store, jomfruelige muslingbanker som besto av store og gamle muslinger i store mengder. Men skrapingen har senere utviklet seg veldig forskjellig i ulike områder, bl.a. med drastisk tilbakegang i fangstmengden ved Island og Norge.

Den islandske muslingskrapingen begynte i 1969. Landingene i Breidafjordur på det vestlige Island, hvor de største muslingbankene fantes, toppet seg i 1985 og 1986 med landinger opp til 12700 tonn. Men etter det ble fangsten redusert til mellom 7500 og 9000 tonn i perioden fra 1994 til 2000. Samtidig ble en mengde parasitter oppdaget i mange voksne muslinger, og i 2003 ble skrapingen stoppet helt som et forebyggende tiltak.
Offshore muslingskraping startet i 1984 i Norge, etter oppdagelsen av store muslingbanker utenfor Jan Mayen. Da disse var tømt i 1986, dro flåten videre til Svalbard. De årlige fangstene toppet seg med 44100 tonn i 1987 og falt deretter til 3000-7000 tonn fram til 1995, da øygruppen ble lukket for bunnskraping. Tilgjengelige data viser en tilbakegang $i$ bestandene mer enn ti år etter at skrapingen opphørte, men i den senere tid er det registrert tegn til at bestandene vokser .

På Grønland ble skraping av kamskjell startet i 1983. Størst fangst oppnås fra Nuuk, der de årlige landingene, mellom 1984 og 2002, lå på omkring 580 tonn. Ingen feltundersøkelser er utført 

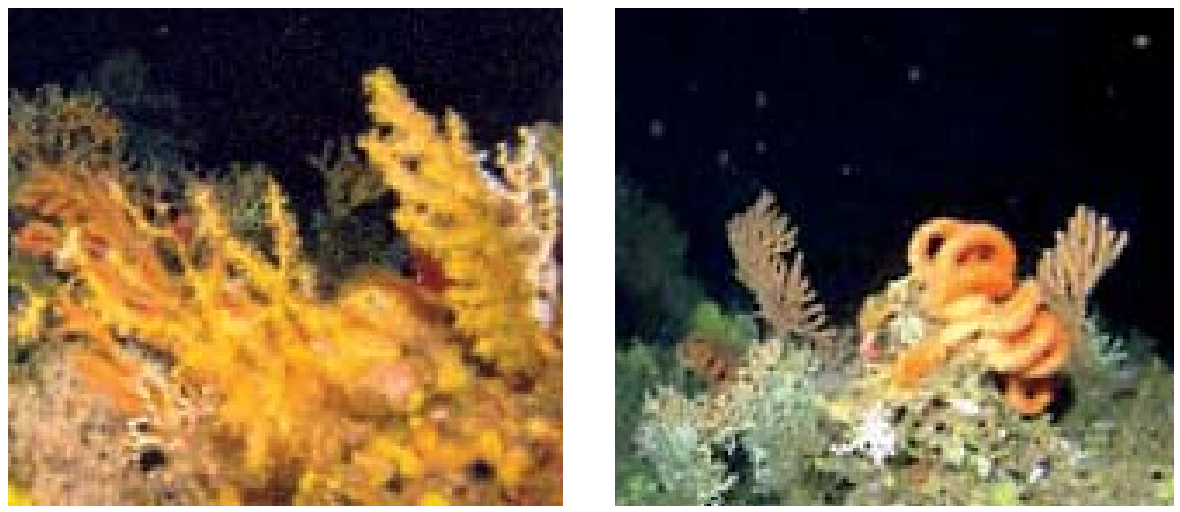

Artsrikt korallrev ved Hornafjorddypet (foto: S. A. Steingrímsson)

siden slutten av 1980-tallet, men det finnes indikasjoner på at hver enkelt muslingbanke utsettes for omfattende skraping, før flåten deretter flytter videre til nye områder. Den totale tillatte fangsten er fastsatt til 2000 tonn per år.

Effekten av bunnskraping på bunndyrsamfunnene er blitt unders $ø$ kt ved Breidafjordur gjennom analyser av bifangstdata. Det viste seg at dyresamfunnene på havbunnen hadde lavt artsmangfold av makrofauna. Dyresamfunnene besto hovedsakelig av bløtdyr med hardt skall, sjøpølser, krabber og sjøstjerner. Dette er dyregrupper som karakteriserer et forstyrret habitat. Imidlertid ble det ikke funnet klare korrelasjoner mellom fiskeritrykket og fordelingen og forekomsten av forskjellige typer bifangst. Studier fra andre land har imidlertid konkludert med at effekten av bunnskraping er mest alvorlig i en tidlig fase av skrapingen. Skraping av muslinger ved Breidafjordur startet opp i 1970, men informasjonen om bifangst går bare tilbake til 1993. Av den grunn er det mulig at bunnskraping, allerede før 1993, hadde forandret dyresamfunnene på havbunnen ved å utrydde alle de sårbare artene fra muslingbankene ved Breidafjordur.

\section{Rekefiske}

Offshore rekefiske startet i 1975 på Island, og i 1995 var landingene steget til 66000 tonn. Siden 1997 er fangsten blitt mindre, og den minste fangsten i perioden fra 1998-2003 var på 21000 tonn i 2000.

Grønlands offshore rekefiske er det største i den nordøstlige delen av Atlanterhavet, og reker har vært Grønlands viktigste eksportvare siden torskefisket kollapset. Rekefisket begynte i 1970 med landinger på 1200 tonn og toppet seg i 2004 med en fangst på 113000 tonn av en bestand anslått til å være 300000 tonn. Fiskerinæringens spektakulære vekst har vært mulig p.g.a. tekniske forbedringer av fiskeflåten, og fordi det opprinnelige fiskeriområdet ved Diskoøya ble utvidet til å omfatte hele den grønlandske vestkysten sør for $75^{\circ} \mathrm{N}$.

Hovedproblemet med det grønlandske rekefisket er at bankene overlapper med yngleområdene for uer, hellefisk, torsk og andre bunnfisk. Dette har nylig ført til et

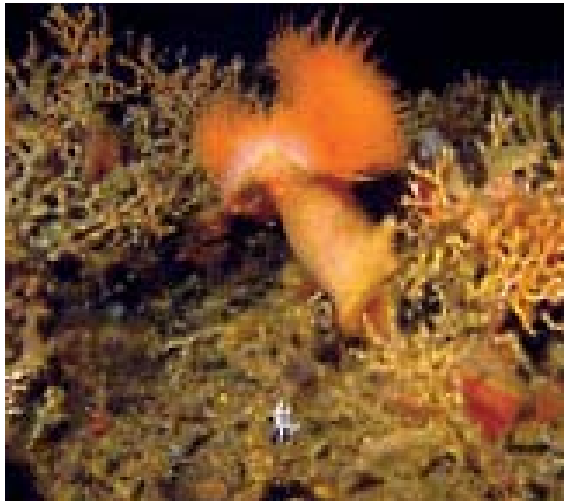

påbud om bruk av sorteringsrister og stenging av rekebankene hvis mengden bifangst overskrider et visst nivå.

Norges offshore rekefiske startet i 1973, og de viktigste fiskebankene finnes rundt Svalbard og i Barentshavet. Fangsten og bestandene varierer mye. Rekebestandenes størrelse ser ut til å avhenge av forekomsten av rovfisk, især torsk, samt den hydrografiske variabiliteten $i$ området, inklusiv beliggenheten av polarfronten. Fisket er ikke regulert med kvoter for den totalt tillatte fangsten, men med lisenser, minimumsstørrelse på rekene, samt maksimalgrense for bifangst. Innføring av sorteringsrist i 1991 var ikke nok for å løse problemet med bifangst, og siden 1993 er en bioøkonomisk modell blitt brukt for å estimere den tillatte maksimale bifangsten av kommersielle fiskearter. Imidlertid har denne strategien ikke ført til det forventede resultatet; bestandene av alle de kommersielle fiskeartene på rekebankene ligger for tiden under de biologiske sikre grensene. Rekefiskets effekt på bunnfisksamfunnene utenfor det nordlige Island er blitt unders $ø$ kt ved analyser av bifangstdata. 

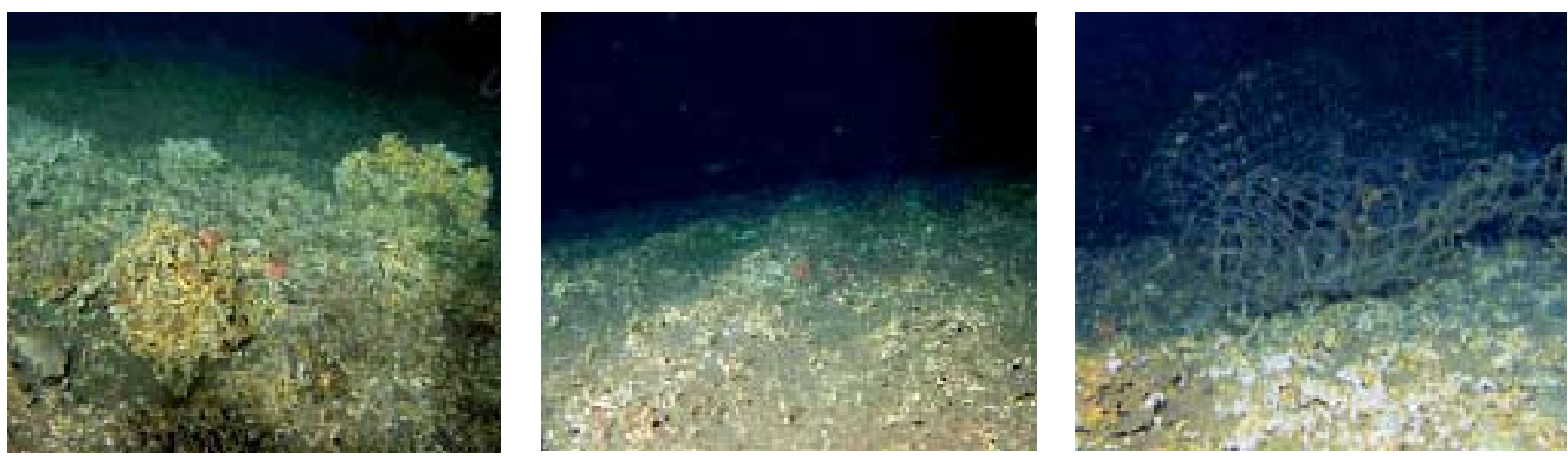

Ødelagt korallrev. Til venstre: Avbrekte levende kolonier. I midten: Fure i havbunnen. Til høyre: Rester av fiskeutstyr (foto: S. A. Steingrímsson).
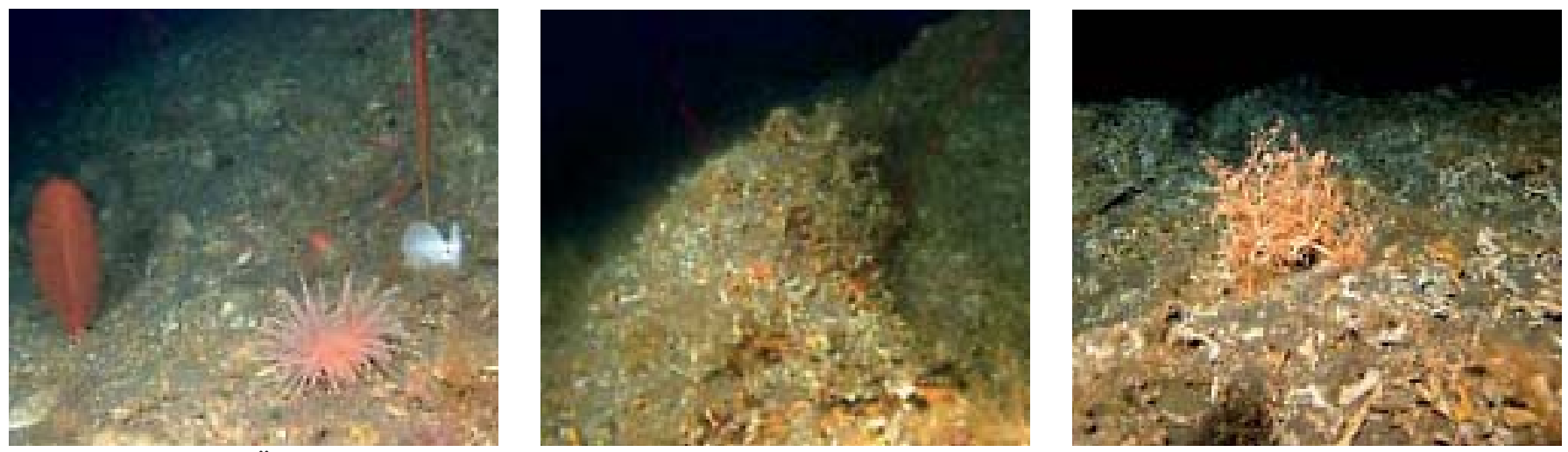

Ødelagt koralrev ved Öræfagrunn, sørøst-Island, på ca. 250 m dybde (foto: S. A. Steingrímsson).

I perioden 1988-1994, før introduksjonen av sorteringsrist i 1995, representerte den innrapporterte bifangsten mellom 2,7 og 7,3 prosent av rekefangsten. I alt 71 fiskearter er blitt registrert ved forskjellige undersøkelser, men forekomsten av bunnfisk har sunket siden 1997 på tross av at den kommersielle flåten av reketrålere har redusert bifangsten betydelig.

\section{Såre habitater}

I de nordiske havområdene finnes det myke dypvannskoraller og harde steinaktige dypvannskoraller, slik som Lophelia pertusa, som danner rev. Det finnes Lophelia-rev langs hele norskekysten, der noen av korallrevene har en utstrekning på opp til 40 kilometer, samt ved kysten av Island. Det er ikke funnet noen Lophelia-rev ved Grønland. Utenfor kysten av Island finnes det myke koraller opp Reykanesryggen og langs med det sørøstlige Island. Den geografiske fordelingen av myke koraller utenfor kysten av Norge vet man fortsatt lite om.

Dypvannskoraller er skjøre, vokser sakte og kan bli flere hundre år gamle. Derfor er koraller veldig sårbare ovenfor bunntråling. Gjenoppretting av et område med $\emptyset$ delagte koraller kan sannsynligvis ta århundrer. Korallene danner viktige habitater for mange bunnfisker og virvelløse dyr, og hvis korallrev ødelegges kan de tilknyttede artene få store problemer med å opprettholde bestandene.
Det antas at mellom 30 og 50 prosent av områdene med korallrev utenfor norskekysten er skadet eller påvirket. Opplysninger fra islandske fiskere tyder på at noen korallrev utenfor Island ble ødelagt av bunntråling i 1980- og 1990-tallet. Alvorlige skader på korallrev utenfor Norge og Island er blitt dokumentert ved hjelp av undervannsfotografering.

I 1999 vernet Norge kaldtvannskoraller mot bunntråling og skraping av muslinger som det første europeiske landet. Inntil videre er fem korallrev, med en samlet utstrekning på $1900 \mathrm{~km}^{2}$, vernet. Den 1. januar 2006 vedtok Island å verne fem korallrev med et areal på til sammen $80 \mathrm{~km}^{2}$. 


\section{Arkeologi på havbunnen}

Forholdene i det arktiske havet er nærmest ideelle for å bevare skipsvrak, som er funnet med intakte master, skrog og overbygg etter 150 år på havbunnen. Et velbevart skipsvrak er en slags tidskapsel, der lite er tilføyd eller blitt ødelagt av senere hendelser i motsetning til hva som er normalt med arkeologiske funn på land.

Bunntråling og -skraping medfører store skader på vrak av treskip, fordi fiskeredskapene smadrer, flytter og reduserer vraket ved en eneste passering. Arbeidsgruppas undersøkelser tyder på at det finnes mange steder i Barentshavet, med muligheter for arkeologiske funn, som overlapper med fiskebankene der det bunntråles i stort omfang.

Det er derfor viktig å tvinge gjennom overholdelsen av den lovmessige forpliktelsen i Norden om å rapportere om skipsvrak. I følge arbeidsgruppas undersøkelser har verken fiskeriflåtene eller overvåkningsskip noensinne, eller sjelden overholdt loven.

I øyeblikket er det bare miljøloven på Svalbard som beskytter arkeologiske lokaliteter på havbunnen mot tråling og bunnskraping innenfor en radius på 100 meter fra det arkeologiske funnet.

Andre sårbare habitater på havbunnen i nordiske farvann er svampsamfunn av store svamper, kolonier av røde kalkalger og hydrothermale kilder.

\section{Anbefalinger}

Den tverrfaglige arbeidsgruppa har satt ned ti anbefalinger i tre kategorier, inklusiv det følgende:

\section{Kartlegging av habitater:}

- Det bør settes av større ressurser til kartlegging av områder på havbunnen med uforstyrrede habitater og kulturminner for å beskytte dem før de skades av fiskeredskap.
Områder som er blitt isfrie de senere årene bør prioriteres.

- Detaljerte kart over sårbare habitater er viktige for framtidige studier av deres økologiske funksjoner og betydning.

\section{Forskning:}

- Man bør øke den biologiske og økologiske forskningen i dypvannskorallrevene og -skogene. Det samme gjelder for svamper, røde kalkalger og hydrothermale kilder. Alle disse sårbare habitatene er viktige for den generelle biodiversiteten i havet og som levesteder for bunnfisk. Vår for- ståelse av disse økosystemene er fortsatt mangelfull.

- Forskning på fiskets påvikning på havbunnen bør styrkes.

\section{Forvaltning:}

- Sårbare habitater, som korallrev og områder med store svamper, bør beskyttes. Det er nødvendig å utvikle og innføre forebyggende reguleringer for å forhindre ytterligere ødeleggelser på grunn av menneskelig aktivitet.

- Forvaltning av muslingbestandene bør forbedres, eksempelvis ved en forbedret vurdering av bestandene, permanent stenging av de områdene der muslinglarvene vokser opp, heve det tillatte minstemålet på muslingene, lavere fisketrykk og introduksjon av rotasjonsordninger for fisket.

- Det bør gjennomføres miljøvurderinger før det gis tillatelser til fiske i hittil uberørte områder.

- Lover bør beskytte kulturminnene på havbunnen, og forvaltningsmyndighetene bør sikre at de implementeres på internasjonalt, regionalt og nasjonalt nivå.

Rapport: TemaNord 2006:529 “Bottom trawling and scallop dredging in the Arctic - Impacts of fishing on non-target species, vulnerable habitats and cultural heritage".

Søk også etter rapporten/emnet på: www.norden.org/pub 


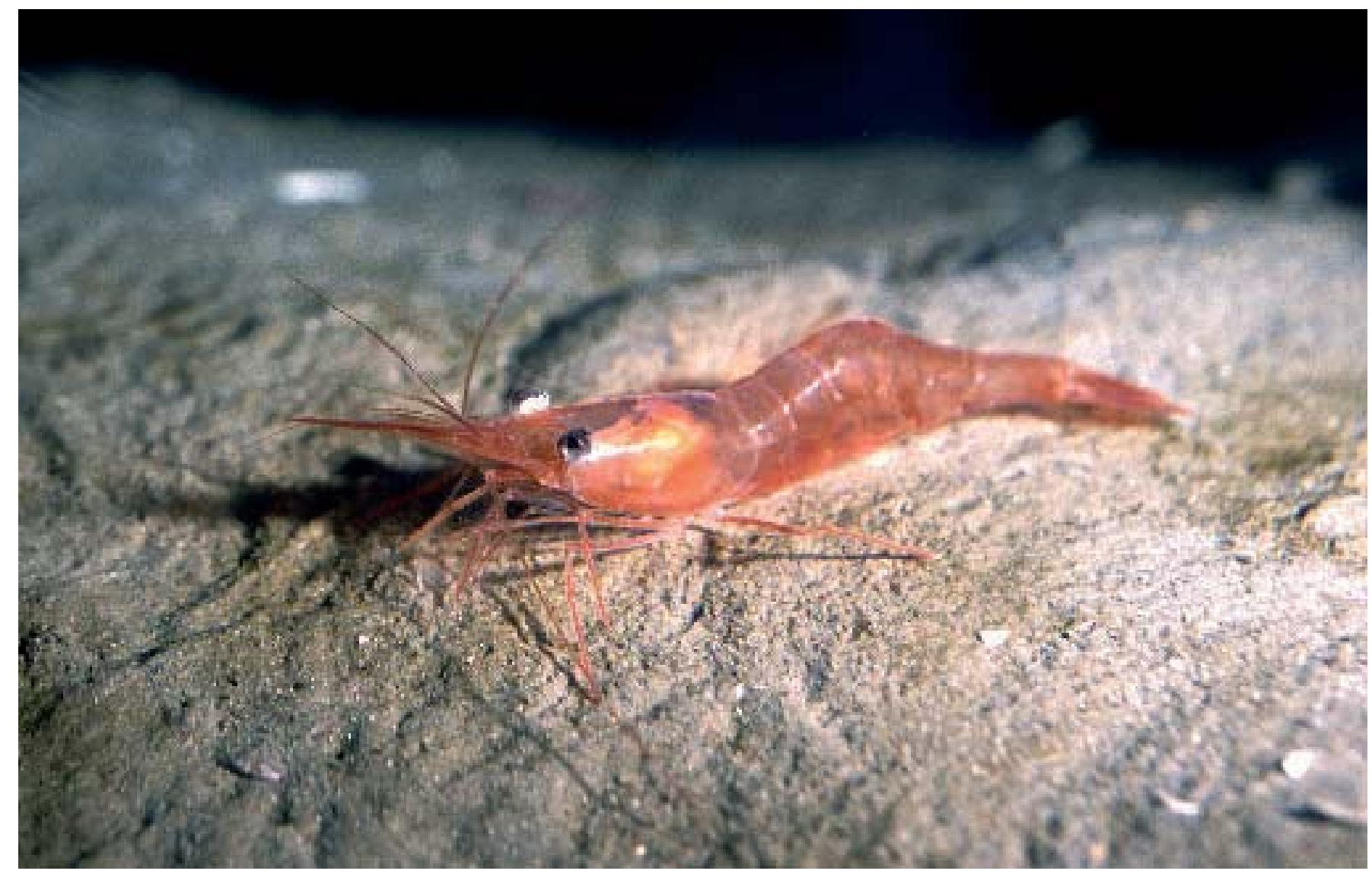

Dyphavsreke (foto: Dieter Betz/Scanpix) 